\title{
Polyphonic Federalism: State Constitutions in the Federal Courts
}

\author{
Robert A. Schapiro $\dagger$
}

\section{TABLe of Contents}

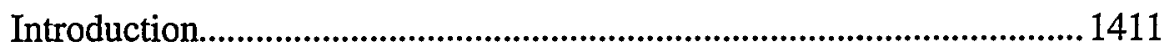

I. Federal Courts Doctrine and State Constitutions ............................. 1418

A. Siler: Avoiding Federal Constitutional Claims ...........................1418

B. State Forum for Certain State Issues ......................................... 1418

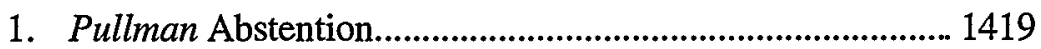

2. Certification ..........................................................................1420

3. Declining Supplemental Jurisdiction ...................................1421

4. The Supreme Court's New Federalism:

The Implications of Pennhurst..............................................1423

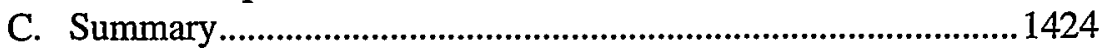

II. Current Supreme Court Doctrine on

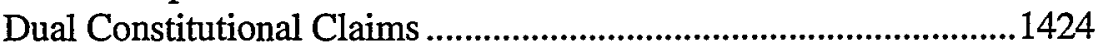

A. Evolution of Supreme Court Treatment of

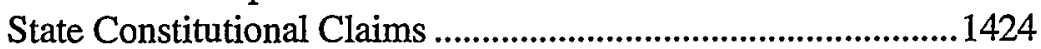

B. Justification for the Doctrine ................................................... 1427

C. The Impact of the New Judicial Federalism ................................1429

III. The Current Lower Court Treatment of Dual

Constitutional Cliallenges ...................................................................1431

A. Option One: Federal Court Decides the

Federal Question.

B. Option Two: Federal Court Allows the

State Court to Address the State Claim

Copyright (C) 1999 California Law Review, Inc.

$\dagger$ Associate Professor of Law, Emory University School of Law. My thanks to Thomas C. Arthur, Susan A. Bandes, William W. Buzbee, William Ty Mayton, Marc L. Miller, Robert J. Pushaw, Jr., and Michael L. Wells for their helpful comments and suggestions. Thanks also to Terry Gordon and William J. Haines of the Emory Law School Library and to David A. Bradley, C. Shane Keith, J. Marcus Meeks, and David Rabinowoitz for their skilled research assistance. 
C. Option Three: Federal Court Decides the

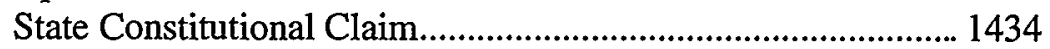

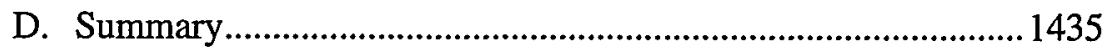

IV. The Myth of State Court Superiority?...........................................1436

A. Structural Protection ...................................................................1438

B. The Diversity Model of Supplemental Jurisdiction.....................1442

C. Federal Voice in a Continuing Constitutional Dialogue .............1446

D. Weakness in State Constitutionalism .........................................1449

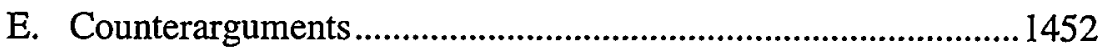

1. Political Accountability and Legitimacy ............................1452

a. In Defense of Democracy .............................................. 1452

b. The Benefits of Soft Law ............................................ 1454

2. The Accidental Character of Supplemental Jurisdiction ....1455

3. Undermining State Constitutionalism ....................................1456

a. The Perverse Incentives of Federal Enforcement.......... 1456

b. The Danger of Federal Monologue ...............................1459

F. Dual Constitutionalism in Practice: California Crosses ............1459

V. Federal Courts and State Law ...........................................................1461

A. Interests Implicated by Dual Constitutional Challenges .............1462

B. Types of State Constitutional Provisions....................................1463

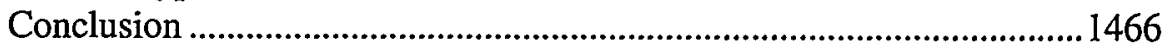




\title{
Polyphonic Federalism: State Constitutions in the Federal Courts
}

\author{
Robert A. Schapiro
}

Because of the growing attention to state constitutions as independent sources of individual rights, plaintiffs increasingly raise claims under both state and federal constitutions. When brought in federal court, these dual challenges pose difficult jurisdictional problems. Adjudicating the state claim furthers the policy of avoiding federal constitutional questions, but presents the risk of federal intrusion into sensitive state policies. To resolve these doctrinal tensions, some courts invoke abstention to allow a state court to decide the state claim. This use of abstention, however, routes the federal constitutional issue through state court, substantially delaying the adjudication of the federal claim and impeding access to the federal forum. This Article develops a new framework for federal treatment of state constitutional claims. By analyzing the premises of existing federal courts doctrine in the novel context of dual constitutional challenges, the Article defends a robust role for federal courts in interpreting state constitutions. The Article argues that, in the proper circumstances, federal adjudication promotes the vindication of constitutional rights while facilitating a valuable federal-state dialogue regarding the scope of individual liberty. Recent litigation concerning the public display of religious symbols illustrates the benefits of federal interpretation of state constitutions.

\section{INTRODUCTION}

In a world increasingly characterized by international interactions, legal norms arise from a variety of sources and find application in divergent forums. The concept of a unified sovereign that both grounds a particular law and authorizes the interpreting court is thus giving way to a more polyphonic legal regime in which law has multiple sources and multiple interpreters. ${ }^{1}$ Similarly, in our federalist polity, intersystemic

1. Polyphony involves multiple independent voices, as opposed to a single, authoritative voice of command. For a discussion of polyphony and its place in political and legal discourse, see Milner S. Ball, Stories of Origins and Constitutional Possibilities, 87 MrcH. L. REv. 2280, 2288-95 (1989); Robert Rubinson, The Polyphonic Courtroom: Expanding the Possibilities of Judicial Discourse, 101 DrCK. L. REv. 3 (1996); see also Amelie Oksenberg Rorty, Varieties of Pluralism in a Polyphonic Society, 44 Rev. MeTaphysics 3, 18-20 (Sept. 1990) (discussing polyphony and pluralism). These 
adjudication is common. State courts interpret federal law, and federal courts construe state law. ${ }^{2}$ The United States Supreme Court recently asserted that the ability, indeed at times the obligation, to enforce the law of another sovereign is a distinctive feature of courts. ${ }^{3}$ In light of this overlapping jurisdictional structure, the allocation of issues between state and federal forums presents difficult problems and has given rise to complex jurisdictional doctrines. ${ }^{4}$

The increased attention to state constitutions as sources of rights independent of the Federal Constitution, a development known as the "new judicial federalism,"5 has produced a novel kind of forum allocation problem that tests the assumptions of current jurisdictional principles. Parties

authors build on the concept of polyphony developed by literary theorist Mikhail Bakhtin. See, e.g., M.M. Bakhtin, The Dialogic Imagination (Caryl Emerson \& Michael Holquist trans., 1981).

2. State and federal courts also may apply the law of other nations. See Louis Henkin, International LAw: Politics ANd VAlues 261 (1995).

3. See Printz v. United States, 521 U.S. 898, 907 (1997) (distinguishing between supposedly unprecedented imposition of obligation on state executives or legislatures to enforce federal law and imposition of such an obligation on courts, which "applied the law of other sovereigns all the time").

4. For example, some scholars posit a primary role for state courts in adjudicating both state and federal disputes. See LARRY W. YACKLE, Federal Courts 13-15 (1999) (describing "Hart and Wechsler Paradigm"); Richard H. Fallon, The Ideologies of Federal Courts Law, 74 VA. L. REv. 1141, 1151-57 (describing "Federalist" model of judicial federalism). One of the classic expositions of this model can be found in Henry M. Hart, Jr., The Power of Congress to Limit the Jurisdiction of Federal Courts: An Exercise in Dialectic, 66 HARv. L. REv. 1362 (1953).

Other commentators have snggested an alternative allocation based on the law governing the case, with federal courts focusing on federal claims and state courts hearing state claims. See England v. Louisiana State Bd. of Med. Exam'rs, 375 U.S. 411, 415-16 (1964) ("[R]ecognition of the rolc of the state courts as the final expositors of state law implies no disregard for the primacy of the federal judiciary in deciding questions of federal law."); FELIX FRANKFURTER \& JAMES M. LANDIS, THE Business OF THE SUPREME COURT 65 (1928) (terming federal courts the "primary and powerful reliances for vindicating" federal rights); Martha A. Field, Abstention in Constitutional Cases: The Scope of the Pullman Abstention Doctrine, 122 U. PA. L. Rev. 1071, 1084-85 (1974); Rex E. Lee \& Richard G. Wilkens, An Analysis of Supplemental Jurisdiction and Abstention with Recommendations for Legislative Action, 1990 BYU L. REv. 321, 334 ("highest and best use" of fcderal courts is deciding federal questions); $c f$. Paul M. Bator, The State Courts and Federal Constitutional Litigation, 22 WM. \& MARY L. REv. 605, 607 (1981) (attributing to Charles Alan Wright the statement that "federal courts should adjudicate issues of federal law; state courts should adjudicate issues of state law").

Neither view promotes federal adjudication of state law. Diversity jurisdiction provides a rare example of the cross-cutting principle that the special characteristics of federal courts make them superior locations for some state-law disputes. See Burt Neuborne, Parity Revisited: The Uses of a Judicial Forum of Excellence, 44 DEPAUL L. REv. 797, 808 (1995) (finding a historical practice of routing important matters, state and federal, into federal courts). In this Article, I contend that the interpretation of state constitutions represents an additional area in which federal courts have an especially valuable role.

5. For a recent overview of the "new judicial federalism," see G. Alan Tarr, The New Judicial Federalism in Perspective, 72 Notre DAME L. REv. 1097, 1112-13 (1997) (discussing growth of "new judicial federalism"); see also Jennifer Friesen, Adventures in Federalism: Some Observations on the Overlapping Spheres of State and Federal Constitutional Law, 3 WIDENER J. PUB. L. 25 (1993) (same). Reviewing published studies, Professor Tarr finds that from 1950 to 1969 , state courts relied on state constitutions to afford greater protection than was available under the constitution only 10 times. By contrast, from 1970 to 1986 , state courts did so in over three hundred cases. See G. ALAN TARR, Understanding State Constitutions 165-66 (1998). 
now often assert both state and federal constitutional claims in a federal court, relying on the court's supplemental jurisdiction over the state claims. ${ }^{6}$ Citizens objecting to public religious displays, for example, have invoked the "No Preference" clause of the California Constitution along with the Federal Establishment Clause, and plaintiffs have relied on both the New York Constitution's broad guarantee of free expression and the federal protections of free speech to challenge restrictions on the location of "adult establishments." Because state constitutional claims generally present an assertion of individual rights against a state defendant, such claims raise issues both more fundamental to individual liberties and more central to state autonomy than the state-law claims typically asserted in federal litigation.

Current federal case law offers contradictory signals on the proper handling of dual state and federal constitutional challenges brought in federal court. ${ }^{9}$ On the one hand, it is well established that federal courts should seek to avoid deciding federal constitutional questions except when absolutely necessary. ${ }^{10}$ This principle suggests that federal courts should adjudicate the state claim, reaching the federal constitutional question only if the state issue fails to resolve the case." On the other hand, the nonauthoritative character of federal interpretation of state law suggests that the federal court might seek to avoid the state constitutional claim. ${ }^{12}$ The

6. See Jennifer Friesen, State Constitutional Law: Litigating Individual Rights, Claims, AND DEFENSES 34 (2d ed. 1996) (citing an increasing frequency of state constitutional claims in federal court).

7. See Murphy v. Bilbray, 782 F. Supp. 1420 (S.D. Cal. 1991), aff d sub nom. Ellis v. City of La Mesa, 990 F.2d 1518 (9th Cir. 1993) (relying on Article I, section 4 of the California Constitution, which states: "Free exercise and cnjoyment of religion without discrimination or preference are guaranteed."). Murphy v. Bilbray is discussed below at text accompanying notes 232-45.

8. See Hickerson v. City of New York, 932 F. Supp. 550 (S.D.N.Y. 1996) (discussing Article I, section 8 of the New York Constitution, which states: "Every citizen may freely speak, write and publish his sentiments on all subjects, being responsible for the abuse of that right; and no law shall be passed to restrain or abridge the liberty of speech or of the press."). Hickerson is discussed below at text accompanying notes 108-11.

9. See ERwin Chemerinsky, Federal JuRisdiction 695 n.35 (2d ed. 1994) (describing allocation of dual constitutional claims as an "interesting and unresolved question").

10. See Ashwander v. Tennessee Valley Auth., 297 U.S. 288, 346-47 (1936) (Brandeis, J., concurring); Siler v. Louisville \& Nashville R.R. Co., 213 U.S. 175, 193 (1909); Lisa A. Kloppenberg, Avoiding Constitutional Questions, 35 B.C. L. REv. 1003 (1994).

11. See FrIESEN, supra note 6 , at 31 .

12. When a court, state or federal, addresses a federal constitutional claim, that interpretation may be reviewed by the United States Supreme Court. See Martin v. Hunter's Lessee, 14 U.S. (1 Wheat.) 304 (1816). Authoritative construction of the federal provision is available in theory, if not always in practice. See Akhil Reed Amar, Parity as a Constitutional Question, 71 B.U. L. REv. 645, 646 (1991) (discussing inability of Unitcd States Supreme Court to review all state court determinations of federal questions). In this sense, state courts function as lower federal courts when addressing federal issues. See Michael C. Dorf, Prediction and the Rule of Law, 42 UCLA L. REv. 651, 660 n.30 (1995). With regard to state-law issues, all federal courts, including the United States Supreme Court, function as lower courts in that they lack final authority over the legal question under adjudication. See id. 
principle of federalism suggests the exercise of further caution when state law is being applied against a governmental actor, as is almost always the case in a constitutional setting. Indeed, the United States Supreme Court has held that if the defendant is a state official or entity, as opposed to a local body, the federalism concerns embodied in the Eleventh Amendment absolutely prohibit a federal court from adjudicating the state-law claim. ${ }^{13}$ Abstention, certification, and declining supplemental jurisdiction allow federal courts to avoid deciding the state issue, but only at the cost of burdening access to a federal forum for the assertion of federal rights. ${ }^{14}$ ln view of the conflict in applicable principles, it is not surprising that federal courts treat dual constitutional challenges with little consistency. ${ }^{15}$

Current scholarship offers limited guidance. Some scholars view the Federal Constitution as the primary guarantor of individual rights and federal courts as the primary protectors of these liberties. ${ }^{16}$ From this perspective, state law tends to be a distraction or an obstruction, a way for defendants to delay the plaintiffs' efforts to vindicate important rights. This model does not recognize the development of independent state constitutional protections. Other scholars have acknowledged the important place of state law in safeguarding individual rights. ${ }^{17}$ These scholars, though, often offer an idealized version of state courts, focusing on the possible

13. See Pennhurst State Sch. \& Hosp. v. Halderman, 465 U.S. 89 (1984). Pennhurst bars statelaw injunctive actions against the state. Suits seeking damages or other retrospective relief against the state also are barred by the Eleventh Amendment. See Edelman v. Jordan, 415 U.S. 651 (1974). Damages actions against officers in their individual capacity are permitted, as such suits are not deemed actions against the state. See Hafer v. Melo, 502 U.S. 21, 30 (1991).

14. See infra text accompanying notes 34-54.

15. Only in the Ninth Circuit, which mandates that the state claim be addressed first, has a definite practice developed. The Ninth Circuit, though, has never fully explained its doctrine. In Carreras v. City of Anaheim, 768 F.2d 1039 (9th Cir. 1985), the Ninth Circuit cited Askew v. Hargrave, 401 U.S. 476 (1971), for the proposition that federal courts should rely on state constitutional provisions so as to avoid adjudicating federal constitutional issues. As Carreras acknowledged, however, in Askew the United States Supreme Court did not itself decide the state constitutional question, but instead ordered abstention. See Carreras, 768 F.2d at 1043 n.5. Carreras does not discuss whether Askew's preference for state constitutional grounds should apply outside of the abstention context. See John E. Simonett, An Introduction to Essays on the Minnesota Constitution, 20 WM. Mitchell L. REv. 227, $236 \mathrm{n} .47$ (1994) (questioning use of Askew as authority outside of the abstention context). Recent cases follow this circuit precedent but question its logic. See Brown v. Woodland Joint Unified Sch. Dist., 27 F.3d 1373, 1384 (9th Cir. 1994) (noting that abstention under Pullman was "appropriate," but relying on circuit precedent to uphold decision not to abstain).

While generally less inclined to decide state constitutional issues, courts in other circuits follow a variety of different approaches. The Eleventh Circuit in particular has resisted adjudication of state constitutional claims. See infra note 102 and accompanying text. The different approaches courts have adopted are discussed infra at text accompanying notes 91-114.

16. See Fallon, supra note 4, at 1158-64 (describing "Nationalist" model of judicial federalism).

17. See Ann Althouse, How to Build a Separate Sphere: Federal Courts and State Power, 100 HARV. L. REv, 1485, 1521-24 (1987) (discussing with approval the holding of the United States Supreme Court in Pennhurst State Sch. \& Hosp. v. Halderman, 465 U.S. 89 (1984)); see also Barry Friedman, A Revisionist Theory of Abstention, 88 Mich. L. REv. 530 (1989) (providing a theoretical justification for abstention doctrines). 
development of an independent jurisprudence of rights, without addressing the often disappointing reality. State court experience, in fact, has demonstrated the unfortunate, but unsurprising, truth that elected judiciaries have difficulty protecting individual rights against majoritarian forces. ${ }^{18}$ This record seeins unlikely to change, as the political pressures on state court judges appear to be increasing to even greater heights. ${ }^{19}$ In brief, if you doubt that life tenure matters, look at Texas. ${ }^{20}$

In view of the growth in state constitutional litigation, the treatinent of state constitutional claims by federal courts will become increasingly significant. Particularly now that the Warren Court's era of judicial expansion of federal rights appears to be past, ${ }^{21}$ the interpretation of the rights-granting clauses of state constitutions will play an important role in defining the scope of civil liberties available to the citizens of each state. ${ }^{22}$ Federal courts must find a way to participate in the growth of state

18. See infra note 182 (citing sources).

19. See infra note 128 (citing sources). Forum allocation doctrines that ignore this aspect of state constitutionalism may actually impede, rather than promote, the vindication of individual rights. For example, a federal court's abstaining from deciding a federal constitutional claim to allow a state court to consider a state constitutional claim may greatly delay the constitutional litigation. See Part III.B infra.

20. Scholars have noted with alarm the effects of highly politicized campaigns for judicial office in Texas. See ABA Comm. on Professionalism, '.. In the Spirit of Public Service:' A Blueprint for the Rekindling of Lawyer Professionalism, 112 F.R.D. 243, 293 (1986) (discussing problems of an elective judiciary and singling out Texas as particular source of concern); Craig Enoch, Annual Survey of Texas Law-Foreword, 48 SMU L. Rev. 723, 723-25 (1995) (describing Texas judicial election system); John L. Hill, Taking Texas Judges Out of Politics: An Argument for Merit Selection, 40 BAYLOR L. REv. 339, 340-43 (1988) (article by former Chief Justice of the Supreme Court of Texas describing "crisis" in Texas judiciary); Thomas R. Phillips, Comment, 61 LAw \& ConTEMP. ProBs. 127 (1998) (article by current Chief Justice of the Supreme Court of Texas discussing need to reform Texas system of judicial elections, while rejecting notion that judges who accept campaign contributions cannot be impartial); Kate Thomas, Are Justices in Texas Getting Bought, NAT'L L.J., Mar. 16, 1998, at A8 (reporting large campaign contributions to judges from parties before the court and quoting Chief Justice of Texas Supreme Court as saying "[R]estoring public confidence in our courts depends on comprehensive judicial reform"); see also Anthony Champagne, Judicial Reform in Texas, in JUDICIAL REFORM IN THE StATEs 93 (Anthony Champagne \& Judith Haydel eds., 1993) (describing judicial elections in Texas); Gregory S. Thielemann, Local Advantage in Campaign Financing: Friends, Neighbors, and Their Money in Texas Supreme Court Elections, 55 J. PoL. 472, 473 (1993) (discussing voter confusion in Texas judicial elections).

21. See William J. Brennan, Jr., The Bill of Rights and the States: The Revival of State Constitutions as Guardians of Individual Rights, 61 N.Y.U. L. Rev. 535, 546 (1986) [hereinafter Brennan, The Bill of Rights]; William J. Brennan, Jr., State Constitutions and the Protection of Individual Rights, 90 HARv. L. Rev. 489, 495-98 (1977) [hereinafter Brennan, State Constitutions]; James L. Oakes, State Courts in a Time of Federal Constitutional Change, 13 VT. L. Rev.323, 324-35 (1988).

22. The significance of state constitutions is underscored by the recent decisions of the United States Supreme Court limiting the ability of Congress to apply federal regulations against the states, see Florida Prepaid Postsecondary Educ. Expense Bd. v. College Sav. Bank, 119 S. Ct. 2199 (1999) (rejecting expansive interpretation of Congress's powers under section 5 of the Fourteenth Amendment), and creating obstacles to the enforcement of federal rights against states, see Alden v. Maine, 119 S. Ct. 2240 (1999) (holding that states enjoy sovereign immunity from suits brought in state courts to enforce federal rights). 
constitutional law without unnecessarily reaching constitutional questions, unduly interfering with important state interests, or unfairly burdening access to a federal forum for the vindication of federal rights.

The goal of this Article is to recognize the theoretical challenges of the new judicial federalism and to bring federal courts doctrine in line with current developments in state constitutional law. Doctrines governing the articulation of state law by federal courts have not kept pace with the theory, or reality, of the increased litigation over state constitutional issues. The principle that "federal courts are far better forums for the vindication of rights than are the state courts"23 must find new meaning in a world in which it is also true that "[s]tate constitutions . . . are a font of individual liberties, their protections often extending beyond those required by the Supreme Court's interpretation of federal law." 24 A reformulated doctrine of federal treatment of state constitutional challenges must harmonize both these principles.

A key element of the reconstructed doctrine is a recognition that federal courts have a significant role in the articulation of state constitutional law and that in the proper circumstances federal court adjudication of state constitutional claims is not a necessary evil, but a positive good. Federal courts are different from state courts. ${ }^{25}$ Reflecting this divergent perspective, federal interpretation of state constitutions can provide a valuable alternative view on fundamental constitutional issues. Moreover, the distinctive structural features of federal courts pose important "reverse parity" issues. ${ }^{26} \mathrm{If}$, as some participants in the "parity" debate suggest, political independence makes federal courts better guarantors of federal

23. LARRY W. YACKLE, Reclaiming the Federal Courts 44 (1994); see also Brennan, The Bill of Rights, supra note 21, at 552 ("Federal courts remain an indispensable safeguard of individual rights against governmental abuse.").

24. Brennan, State Constitutions, supra note 21, at 489; see also Burt Neuborne, State Constitutions and the Evolution of Positive Rights, 20 RUTGERs L.J. 881, 893-98 (1989) (arguing that state constitutions offer more promising sources for positive rights than the Federal Constitution).

25. Federal judges, for example, are federal officials, appointed for life by the President of the United States; state judges, by contrast, are part of the state political system and generally are subject to some form of electoral accountability. See Geoffrey C. Hazard, Jr., Reflections on the Substance of Finality, 70 CoRnell L. REv. 642, 647 (1985) (listing institutional differences between state and federal courts and suggesting that such differences are "synergistically, systematically, and ubiquitously "outcome determinative"').

26. The standard "parity" debate pits those who assert that state and federal courts are equally suitable forums for the adjudication of federal rights against those who argue that federal courts enjoy a structural superiority in addressing federal claims. See Burt Neuborne, The Myth of Parity, 90 HARv. L. Rev. 1105, 1121-27 (1977). For a discussion of the parity debate, see infra Part 1V.A; see also Friedman, supra note 17, at 531 (citing a "widespread perception that state courts are less receptive than federal courts to federal claims of right"). But cf. Bator, supra note 4, at 633 (arguing that constitutional values also may be vindicated by decisions rejecting constitutional challenges). For an examination of the relationship between structure and outcome in the administrative context, see Matthew D. McCubbins et al., Structure and Process, Politics and Policy: Administrative Arrangements and the Political Control of Agencies, 75 VA. L. REv. 431 (1989). 
constitutional rights, are federal courts also better guarantors of state constitutional rights? Or is the appropriate level of judicial insulation determined by the constitution being construed? This Article suggests that the policies underlying the preference for a federal forum for federal constitutional claims, as well the rationales for diversity jurisdiction, justify the federal courts' taking a more active role in addressing state constitutional issues. The concern for avoiding unnecessary constitutional decisions provides added support for a robust federal role. Federal adjudication of state constitutional claims contributes to the development of state constitutional law, while at the same time avoiding a federal constitutional ruling that would end any chance for further dialogue on important constitutional matters. ${ }^{27}$

By formulating an answer to the doctrinal problems posed by dual constitutional challenges, this Article seeks to explore larger themes of interpretation and authority im constitutional law in both the national and international contexts. Part I analyzes the doctrinal framework applicable to dual federal and state constitutional challenges. Part II explains the Supreme Court's treatment of dual constitutional claims and examines the justifications for the Court's holdings. This Part argues that the new judicial federalism has undermined some of the key premises of the Court's analysis. Part III reports the contradictory ways in which lower federal courts currently deal with the problem of dual constitutional challenges. By applying the insights of the parity and diversity debates, Part IV assesses the benefits of federal court adjudication of state constitutional claims and illustrates the advantages of such adjudication by reference to recent litigation concerning government-sponsored displays of religious symbols. Building on the preceding analysis, Part V elaborates a new theory for federal court treatment of dual constitutional claims that recognizes an important role for the federal courts in the development of state constitutional law.

27. If appealed to the United States Supreme Court, a ruling on a federal constitutional question would bind all state and federal courts in future cases. The binding precedential authority of decisions by lower federal courts would be more limited. However, interpretations of state constitutions by federal courts, even by the Supreme Court, could not bind state courts. Indeed, such holdings might have little authority even within federal courts. See Jed I. Bergman, Putting Precedent in its Place: Stare Decisis and Federal Predictions of State Law, 96 CoLuM. L. Rev. 969 (1996) (discussing arguments that federal court interpretations of state law should have limited precedential weight); Nikiforos Mathews, Circuit Court Erie Errors and the District Court's Dilemma: From Roto-Lith and the Mirror Image Rule to Octagon Gas and Asset Securitization, 17 CARDozo L. Rev. 739 (1996) (same). Certainly state courts would remain free to offer contrasting views of the mandates of their state constitutions. 
Federal Courts Doctrine and State Constitutions

Federal courts address issues of state law in a variety of contexts. The power to hear these claims generally rests on diversity ${ }^{28}$ or supplemental ${ }^{29}$ jurisdiction. This Part surveys the doctrinal framework applicable to cases raising both state and federal constitutional claims. The principles of avoiding federal constitutional adjudication, allowing state courts to decide state law, and providing a federal forum for federal claims all play a role in defining the doctrine.

\section{A. Siler: Avoiding Federal Constitutional Claims}

In Siler v. Louisville \& Nashville Railroad Co. ${ }^{30}$ the Supreme Court affirmed the practice of federal courts' deciding state-law claims that arise in the context of federal question cases. Siler concerned a railroad company's challenge under the Federal Constitution to a state administrative order setting maximum rates. The railroad argued that, in addition to violating the Federal Constitution, the order also lacked authorization under state law. The Supreme Court held that the proper course was to adjudicate the state claim so as to avoid rendering a decision under the Federal Constitution. ${ }^{31}$ Siler thus established that federal court adjudication of state-law issues was not only permissible in federal question cases, but indeed was preferable if it allowed the court to avoid a federal constitutional question. The state-law claims in Siler did not rest on the state constitution, but nothing in that opinion, or in subsequent opinions championing the avoidance of federal constitutional questions, ${ }^{32}$ indicated that the source of state law should be relevant. Siler suggests that in addressing a dual constitutional challenge, a federal court should first adjudicate the state constitutional claim. ${ }^{33}$ The Siler approach thus avoids federal constitutional issues, but at the cost of having a federal rather than a state court interpret state law.

\section{B. State Forum for Certain State Issues}

Another strand of federal courts doctrine focuses on ensuring that state courts, rather than federal courts, adjudicate certain state-law issues. Some elements of this strand, such as Pullman abstention, continue to

28. See 28 U.S.C. $\S 1332$ (1994).

29. See id. $\$ 1367$.

30. 213 U.S. 175 (1909).

31. See id. at 192.

32. See, e.g. , Ashwander v. Tennessee Valley Auth., 297 U.S. 288, 346-47 (1936) (Brandeis, J., concurring).

33. See FrIESEN, supra note 6, at 31 ("Deciding any state constitutional claims first is apparently required by the Supreme Court's direction that federal courts avoid unnecessary decisions of fcderal constitutional issues."). 
advance the avoidance principle stated in Siler. Other elements, however, such as the Pennhurst doctrine and declining supplemental jurisdiction, may thwart the avoidance principle.

\section{Pullman Abstention}

The principle that certain state-law issues require resolution in a state, not a federal, court, received its classic statement in Railroad Commission of Texas v. Pullman. ${ }^{34}$ The controversy in Pullman concerned an order of the Texas Railroad Commission requiring that white conductors, rather than black porters, supervise sleeping cars. The Pullman company, the railroads, and intervening porters asserted that the order both violated the Federal Constitution and exceeded the commission's statutory authority. The Siler principle suggested that the Court should decide the state-law allegation of unauthorized rule making before reaching the federal constitutional issues. The Court, however, found another avenue for avoiding the federal constitutional question. Rather than the federal court's deciding the state question, the Court held that the federal courts should abstain from adjudicating the matter and instead allow the state courts to interpret the state statute. ${ }^{35}$ Writing for the Court, Justice Frankfurter justified abstention on two main grounds: avoiding unnecessary adjudication of constitutional claims and avoiding needless interference with legitimate state policies. ${ }^{36}$ He emphasized that a ruling by state courts on the (rather unclear) state law might obviate reaching the federal constitutional question. ${ }^{37}$

Pullman abstention forces plaintiffs to initiate a suit im state court to resolve the state-law issue. The proceedings in federal court remain in abeyance during the pendency of the state action. ${ }^{38}$ By invoking Pullman abstention, a federal court thus avoids the federal constitutional question without undertaking an interpretation of state law. Pullman, however, does burden the plaintiff's choice of forum. Plaintiffs may always reserve the right to have their federal claim heard by a federal court, but only after the state-law issue has been decided by the state court system, including any

34. 312 U.S. 496 (1941).

35. See Julie A. Davies, Pullman and Burford Abstention: Clarifying the Roles of State and Federal Courts in Constitutional Cases, 20 U.C. DAvis L. REv. 1, 7 (1986) (arguing that Pullman abstention "transported the tradition of avoiding constitutional questions to an entirely new dimension" by encouraging "not only decisions on a state law ground, but also decisions by state courts").

36. See Martha A. Field, The Abstention Doctrine Today, 125 U. PA. L. REV. 590, 590 (1977).

37. See 312 U.S. at 498-99. Pullman did not involve a state constitutional issue, but the Court's argument for abstention would apply at least as forcefully to claims resting on the state constitution. In subsequent cases, the Court invoked Pullman abstention to allow a state court to consider state constitutional questions. See Harris County Comm'rs Court v. Moore, 420 U.S. 77 (1975); Reetz v. Bozanich, 397 U.S. 82 (1970).

38. See Richard H. Fallon, Jr. et al., The Federal, Courts and the Federal System 1242 (4th ed. 1996). 
appeals. ${ }^{39}$ Because it forces this circuitous journey, Pullman abstention long has been subject to criticism for delaying, sometimes by years, the adjudication of the federal constitutional claim. ${ }^{40}$ The Supreme Court itself recently acknowledged the problem of delay. ${ }^{41}$ This lag has the effect of burdening access to a federal forum for the adjudication of a federal constitutional right. ${ }^{42}$

\section{Certification}

Certification provides a streamlined alternative to abstention. ${ }^{43}$ Under the certification process, a federal court may request that a state court of last resort rule on an issue of state law. Certification procedures are available in some form in forty-six states, Puerto Rico, and the District of Columbia. ${ }^{44}$ Unlike abstention, certification does not require the litigants to endure a full state court litigation regimen. The parties receive an authoritative interpretation of state law without the need for trial and appeals in the state court system. Because the certification process is relatively expeditious, the United States Supreme Court has expressed a preference for certification over abstention. ${ }^{45}$

Certification, however, does entail some delay, and routing all dual constitutional challenges through a certification process would certainly burden access to the federal forum. Moreover, cases presenting parallel state and federal claims may be less suitable for certification than cases in which the federal issue turns on the construction of a disputed provision of state law. State courts may need full factual development before they can decide whether a state constitutional challenge is meritorious. ${ }^{46}$ Furthermore, some state courts have resisted certification when a dispositive

39. See England v. Louisiana State Bd. of Med. Exam'rs, 375 U.S. 411 (1964); FALLoN, supra note 38, at 1243-44 (4th ed. 1996).

40. See, e.g. , Charles Alan Wright, Law of Federal Courts 325-26 (5th ed. 1994); Field, supra note 4, at 1129-34; Field, supra note 36, at 591 ("The delay and expense inherent in the abstention procedure are legendary ....").

41. See Arizonans for Official English v. Arizona, 520 U.S. 43, 76 (1997).

42. See Field, supra note 4, at 1087; Martin H. Redish, Abstention, Separation of Powers, and the Limits of the Judicial Function, 94 YALE L.J. 71, 90 (1984); Thomas G. Buehanan, Note, Pullman Abstention: Reconsidering the Boundaries, 59 TEMPLE L.Q. 1243, 1247 (1986).

43. For an annotated bibliography of the certification literature, see JoNA GoldSCHMIDT, Certification of Questions of Law: Federalism in Practice 119-37 (1995).

44. See William G. Bassler \& Michael Potenza, Certification Granted: The Practical and Jurisprudential Reasons Why New Jersey Should Adopt a Certification Procedure, 29 Seton Hall L. REv. 491, 493 n.9 (1998); see also GoldsCHMIDT, supra note 43, at 15 . Some of these jurisdictions will accept questions only from federal courts of appeals, not from district courts. See GoLDSCHMIDT, supra note 43 , at $15-16$.

45. See Arizonans for Official English, 520 U.S. at 76.

46. See, e.g., White v. Edgar, 320 A.2d 668, 684 n.17 (Me. 1974) (questioning the use of certification for dual constitutional challenges). 
federal issue exists that would render the state court's answer irrelevant. ${ }^{47}$ In the case of parallel challenges under the state and federal constitutions, such a dispositive federal issue always is present; even if the plaintiffs lose on the state issue, they may still prevail on the federal claim. ${ }^{48}$

\section{Declining Supplemental Jurisdiction}

In the converse of the Siler approach, a court may decline to exercise supplemental jurisdiction over the pendent state constitutional claim. ${ }^{49}$ Under the supplemental jurisdiction statute enacted in 1990, 28 U.S.C. $\S 1367$, a court may refuse jurisdiction over the state claim if it "raises a novel or complex issue of State law."50 Citing comity concerns, some Federal courts have been especially reluctant to construe state constitutional provisions that appear to present novel and complex issues. ${ }^{51}$ The relationship between $\S 1367$ (c) and abstention remains somewhat unclear. ${ }^{52}$

47. See Boyter v. Commissioner, 668 F.2d 1382, 1385-86 (4th Cir. 1981); Yesil v. Reno, 705 N.E.2d 655 (N.Y. 1998) (declining to answer certified question based in part on conclusion that question "is not likely to be dispositive of the matter").

48. See Dolores K. Sloviter, A Federal Judge Views Diversity Jurisdiction Through the Lens of Federalism, 78 VA. L. REv. 1671, 1684-86 \& nn.75-80 (1992) (discussing various problems with certification). To avoid the problem of certifying state-law questions in suits involving potentially determinative federal grounds, courts sometimes have decided the federal issue first, even while acknowledging the deviation from the rule of avoiding unnecessary federal constitutional adjudication. See Petroleum Helicopters, Inc. v. Avco Corp., 804 F.2d 1367 (5th Cir. 1986).

49. See, e.g., Green v. Zendrian, 916 F. Supp. 493, 498 (D. Md. 1996) ("This Court's obligation to avoid making an unnecessary decision in an unsettled area of state constitutional law was an important factor in its decision to remand the state causes of action...."). Refusing supplemental jurisdiction eliminates the possibility of avoiding the federal constitutional question.

50. 28 U.S.C. $\$ 1367$ (c)(1) (1994). In addition, the district court may decline jurisdiction in "exceptional circumstances" based on "other compelling reasons." Id. $\$ 1367$ (d).

51. See Chandler v. Miller, 73 F.3d 1543, 1546 n.3 (11th Cir. 1996) (citing concerns of comity), rev'd on other grounds, 520 U.S. 305 (1997); Young v. New York City Transit Auth., 903 F.2d 146, 164 (2d Cir. 1990) (same); Crenshaw v. Dywan, 34 F. Supp. 2d 707, 713 (N.D. Ind. 1999) (same); 16 JAMES WM. MOORE ET AL., MOORE's FEDERAL PRACTICE $§ 106.64$ (3d ed. 1997); see also Van Harken v. City of Chicago, 103 F.3d 1346, 1354 (7th Cir. 1997) (Posner, J.) (citing constitutional character of state-law claim as supporting decision to decline supplemental jurisdiction); Clajon Prod. Corp. v. Petera, 854 F. Supp. 843, 846 n.1 (D. Wyo. 1994) ("It is hard to imagine issues that are more within the province of state courts than issues requiring interpretation of the state's own constitution."); Escobar v. Landwehr, 837 F. Supp. 284, 289 (W.D. Wis. 1993) ("Claims that arise under the state constitution should be pursued in state courts rather than in federal court."); Freund v. Florio, 795 F. Supp. 702, 710-11 (D.N.J. 1992) (refusing to exercise supplemental jurisdiction over pendent state constitutional claim). For a discussion of declining supplemental jurisdiction as implementing comity concerns, see 16 MOORE ET AL., supra, $\$ 106.66$.

52. Section 1367's codification of novelty and complexity presents some tension with the doctrine of Pullman abstention. Novel and complex claims would seem to be exactly those kinds of issues that would be appropriate for abstention under Pullman. See John B. Oakley, Recent Statutory Changes in the Law of Federal Jurisdiction and Venue: The Judicial Improvements Acts of 1988 and 1990, 24 U.C. Davis L. REv. 735, 766 \& n.118 (1991); David D. Siegel, Commentary on 1988 Revision, 28 U.S.C.A. $\$ 1367$ (West 1997); David D. Siegel, Changes in Federal Jurisdiction and Practice Under the New (Dec. 1990) Judicial Improvements Act, 133 F.R.D. 61, 67 (1991) (noting "overlap" with abstention criteria); Joan Steinman, Section 1367-Another Party Heard From, 41 EMORY L.J. 85, 92 (1992) (noting $§ 1367(\mathrm{c})(1)$ is "redolent of language used in abstention cases"). For 
However, like abstention, declining supplemental jurisdiction can burden access to a federal forum for the vindication of federal rights. One of the purposes of supplemental jurisdiction is to facilitate access to a federal forum by eliminating the need to bifurcate state and federal claims. ${ }^{53}$ Declining supplemental jurisdiction would have the effect of obstructing that access, forcing plaintiffs either to split their claims or to bring both federal and state claims in state court. In view of the potentially similar effects of abstention and decliniug supplemental jurisdiction, some courts have explicitly stated that if abstention is inappropriate, so is declining supplemental jurisdiction. ${ }^{54}$

a different view of the relationship of abstention and $\S 1367(\mathrm{c})$, see 16 MOORE ET AL.,stupra note 51, $\S$ 106.64 \& n.5 (acknowledging that uncertainty of state law has played a role in Pullman abstention, but noting that "the novelty of a state-law issue, in and of itself, has never provided a basis for abstention outside of the supplemental jurisdiction context").

Indeed, one commentator has asserted that $\S 1367$ "appears to overrule Pullman and its progeny" by allowing district courts to dismiss novel and complex claims, rather than abstaining. Arthur D. Wolf, Codification of Supplemental Jurisdiction: Anatomy of a Legislative Proposal, 14 W. NEW ENG. L. Rev. 1, 26 (1992); see also Joseph N. Akrotirianakis, Comment, Learning to Follow Directions: When District Courts Should Decline to Exercise Supplemental Jurisdiction Under 28 U.S.C. \$ 1367(c), 31 LOY. L.A. L. REv. 995, 1021 (1998) (discussing the distinction between declining supplemental jurisdiction and abstaining under Pullman). Moreover, while Pullman abstention is premised on avoiding federal constitutional adjudication, $\S 1367$ (c) appears to make avoidance of statelaw issues an independent goal. See Steven H. Steinglass, Litigating State Employment Discrinination Claims in Federal Courts Under the New Doctrine of Supplemental Jurisdiction, C780 ALI-ABA 467, 490 (1993). A court may decline supplemental jurisdiction even when no federal constitutional claim is present.

53. See Jack H. Friedenthal et al., Civil Procedure $\$ 2.12$, at 69 (2d ed. 1993); see also FAllon ET AL., supra note 38, at 967; George D. Brown, Beyond Pennhurst-Protective Jurisdiction, the Eleventh Amendment, and the Power of Congress to Enlarge Federal Jurisdiction in Response to the Burger Court, 71 VA. L. REv. 343, 357 (1985); John P. Dwyer, Pendent Jurisdiction and the Eleventh Amendment, 75 CALIF. L. REv. 129, 154-56 (1987); Note, A Closer Look at Pendent and Ancillary Jurisdiction: Toward a Theory of Incidental Jurisdiction, 95 HARv. L. Rev. 1935, 1936 (1982); see also Denis F. McLaughlin, The Federal Supplemental Jurisdiction Stature-A Constitutional and Statutory Analysis, 24 ARIZ. ST. L.J. 849, 863-64 (1992) (noting that pendent jurisdiction helps to effectuate one of the "principal purposes" of a federal court system, which is to provide federal forum for the assertion of federal claims); Sidney Schenkier, Ensuring Access to Federal Courts: A Revised Rationale for Pendent Jurisdiction, 75 Nw. U. L. REv. 245, 248 (1980).

Pendent jurisdiction also furthers the convenience of the parties and judicial efficieney by allowing all transactionally related claims to be addressed in one proceeding. See FRIEDENTHAL ET AL, stupra, § 2.12, at 69; Richard D. Freer, Avoiding Duplicative Litigation: Rethinking Plaintiff Autonomy and the Court's Role in Defining the Litigative Unit, 50 U. PITT. L. REv. 809, 813-14 (1989); Richard D. Frcer, Compounding Confusion and Hampering Diversity: Life After Finley and the Supplemental Jurisdiction Statute, 40 EMORY L.J. 445, 449 (1991).

54. See, e.g., Brown v. Woodland Joint Unified Seh. Dist., No. S-91-0032WBS/PAN, 1992 WL 361696, at *5 (E.D. Cal. Apr. 2, 1992) ("[I]f it is not appropriate to abstain it is likewise not appropriate to decline the court's supplemental jurisdiction over the state law claims."), aff'd, 27 F.3d 1373 (9th Cir. 1994). But cf. City of Chicago v. International College of Surgeons, 522 U.S. 156, 174 (1997) ("In addition to their discretion under $\$ 1367$ (c), district courts may be obligatcd not to decide state law claims (or to stay their adjudication) where one of the abstention doctrines articulated by this Court applies." (emphasis added)). 
4. The Supreme Court's New Federalism: The Implications of Pennhurst

Declining supplemental jurisdiction represents a discretionary judgment to avoid federal interpretation of state law. In certain situations involving state defendants, the Supreme Court has held that the interest in avoiding federal adjudication of state claims reaches constitutional magnitude and trumps all competing interests. In Pennhurst State School \& Hospital v. Halderman, ${ }^{55}$ the Supreme Court held that the Eleventh Amendment poses a constitutional bar to federal court adjudication of state-law claims against the state itself. After Pennhurst, federal courts lack jurisdiction to do what the Supreme Court did in Siler: to enjoin a state agency based on state law. In this regard, Pennhurst overruled Siler on its facts. ${ }^{56}$

Pennhurst has significant ramifications for federal court treatment of state constitutional clains. As state constitutional litigation generally involves official defendants, the specific holding or the more general reasoning of Pennhurst will apply in many cases raising state constitutional issues. If the defendant is an arm of the state itself, Pennhurst bars federal court adjudication of the state-law claim for imjunctive relief. If the defendant is, instead, a state subdivision, such as a municipality, the Eleventh Amendment poses no jurisdictional bar. Under established doctrine, municipalities and other subdivisions do not count as the "state" for Eleventh Amendment purposes. ${ }^{57}$ The reasoning of Pennhurst, though, cannot be cabined so easily. The case spoke more broadly of the intrusive nature of enforcing state law against state actors. ${ }^{58}$ These federalism concerns seem relevant even in cases in which the Eleventh Amendment does not apply. ${ }^{59}$ In contrast to the avoidance principle of Siler and Pullman,

55. 465 U.S. 89 (1984).

56. The Court justified the deviation from Siler on the grounds that that case did not explicitly address the Eleventh Amendment issue. See id. at 118. The Court insisted that the Siler principle of avoidance remained controlling when the defendant was not an arm of the state. See id. at 118 n.28.

57. See Lincoln County v. Luning, 133 U.S. 529 (1890).

58. See Pennhurst, 465 U.S. at 106. ("[I]t is difficult to think of a greater intrusion on state sovereignty than when a federal court instructs state officials on how to conform their conduct to state law.").

59. The general relevance of these policies seems particularly salient in light of the difficulty in providing a principled justification for the divergent treatment of states and their subdivisions under the Eleventh Amendment. See Robert A. Schapiro, Balancing, Justice, and the Eleventh Amendment: Justice Stevens' Theory of State Sovereign Immunity, 27 RuTGERs L.J. 563, 597 \& n.119 (1996); see also John V. ORth, The Judicial Power of the United States The Eleventh Amendment in AMERICAN HISTORY 110-20 (1987); William A. Fletcher, A Historical Interpretation of the Eleventh Amendment: A Narrow Construction of an Affirmative Grant of Jurisdiction Rather than a Prohibition Against Jurisdiction, 35 Stan. L. Rev. 1033, 1099-1107 (1983); Gerald E. Frug, The Judicial Power of the Purse, 126 U. PA. L. Rev. 715, 756 (1978); John J. Gibbons, The Eleventh Amendment and State Sovereign Immunity: A Reinterpretation, 83 Colum. L. REv. 1889, 1973-2002 (1983); Vicki C. Jackson, One Hundred Years of Folly: The Eleventh Amendment and the 1988 Term, 64 S. CAL. L. REv. 51, 57 n.23 (1990); Margreth Barrett, Comment, The Denial of Eleventh Amendment Immunity to Political Subdivisions of the States: An Unjustified Strain on Federalism, 1979 DuKE L.J. 1042, 1069. 
then, the rationale of Pennhurst suggests that federal courts should be reluctant to apply state law against government entities.

\section{Summary}

A complex doctrinal franework governs the resolution of dual state and federal constitutional claims. As federal constitutional claims, the dual challenges implicate the avoidance principles of Siler and Pullman. The state-law aspects of the suits involve the federalism issues implicit in Pullman. As state constitutional claims, the challenges are likely to invoke the heightened federalism concerns expressed in Pennhurst. The supplemental jurisdiction statute allows for other comity concerns to weigh against federal adjudication of the state constitutional claims. In short, the doctrines pull in many contradictory directions.

II

Current Supreme Court Doctrine on Dual Constitutional Claims

This Part explores how the Supreme Court has applied the doctrinal framework just surveyed to particular dual constitutional claims. By the end of the 1970s, the Court had reached a relatively stable position on the appropriate method for handhing dual constitutional challenges. If the federal and state claims relied on parallel federal and state constitutional provisions, then the Court decided the federal constitutional claim, rather than abstaining or itself deciding the state constitutional claim. If, instead, the state claim rested on more particularized constitutional provisions that formed part of an integrated state regulatory regime, the Court abstained. This Part first discusses the Supreme Court's exposition of this doctrine, then analyzes its theoretical underpinnings, and finally argues that the new judicial federalism requires reassessment of the doctrine.

\section{A. Evolution of Supreme Court Treatment of State Constitutional Claims}

In addressing the appropriate treatment of supplemental state constitutional claims, the Supreme Court has wrestled with the tension between allowing state courts to interpret state law and facilitating access to a federal forum for federal rights. A broad application of Pullman, ${ }^{60}$ requiring the resolution of state constitutional claims in state court, would erect a substantial, albeit not insurmountable, barrier to the federal courthouse. A narrow construction of the doctrine would diminish the role of state courts in interpreting state law. In a series of cases in the 1970s, the Supreme

But see Melvyn R. Durchslag, Should Political Subdivisions Be Accorded Eleventh Amendment Immunity?, 43 DePAUL L. REv. 577 (1994).

60. Railroad Comm'n of Texas v. Pullman, 312 U.S. 496 (1941). 
Court struggled to define the Pullman doctrine in a way that would properly reconcile these conflicting interests.

After some initial confusion, the Court developed a fairly clear doctrine. The Court held that abstention was appropriate in the case of specialized state constitutional provisions that formed part of an integrated regulatory regime and that had no parallel provision in the Federal Constitution. In Reetz v. Bozanich, ${ }^{61}$ for example, the plaintiffs alleged that new Alaskan fishing regulations violated their rights under the Equal Protection Clause of the Fourteenth Amendment and under unique provisions of the Alaska Constitution relating to fishing. ${ }^{62}$ Noting that the state constitutional provisions had never been interpreted by Alaska courts, the Supreme Court held that the federal courts should abstain while the plaintiffs sought authoritative construction of the Alaska Constitution in state court. ${ }^{63}$ Similarly, in Harris County Commissioners Court v. Moore ${ }^{64}$ the Court faced state and federal constitutional challenges to a redistricting plan that had the effect of removing several local officeholders prior to the expiration of their elected terms. ${ }^{65}$ Reversing a lower court ruling on the merits of the dispute, the Supreme Court ordered abstention to allow a Texas court to consider whether the redistricting violated provisions of the Texas Constitution governing the tenure of the affected offices.

By contrast, the Court rejected abstention in the case of broad state constitutional provisions that paralleled the Federal Constitution. In Wisconsin $v$. Constantineau, ${ }^{66}$ for example, the Court held that a federal court should not abstain to allow state courts to consider a state due process challenge. In Examining Board of Engineers, Architects and Surveyors v. Flores de Otero ${ }^{67}$ and Hawaii Housing Authority v. Midkiff, ${ }^{68}$ the Court similarly concluded that state equal protection and takings provisions did not merit abstention. ${ }^{69}$ The Court offered two principal explanations for its rejection of abstention for parallel constitutional claims.

First, the Court asserted that uncertainty over the meaning of a broad state constitutional provision did not render the underlying state law

61. 397 U.S. 82 (1970).

62. See id. at 84 "'Wherever occurring in thcir natural state, fish, wildlife, and waters are reserved to the people for common use." (quoting ALASKa CoNST. art. VIII, § 3)); id ("No exclusive right or special privilege of fishery shall be crcated or authorized in the natural waters of the State." (quoting ALASKA CoNST. art. VIII, § 15)).

63. See id. at 86.

64. 420 U.S. 77 (1975).

65. See id. at 78-81.

66. 400 U.S. 433 (1971).

67. 426 U.S. $572(1976)$.

68. 467 U.S. 229, 237 n.4 (1984).

69. In an earlier case, Askew v. Hargrave, 401 U.S. 476 (1971) (per curiam), the Court had ordered abstention for a parallel provision of the state constitution, but this practice apparently did not survive Constantineau, Flores de Otero, and Midkiff. 
unclear. ${ }^{70}$ Unless the challenged statute and the constitution together constituted an integrated whole, no reference to the state constitution was required to elucidate the regulatory scheme. The challenged regulation was clear, even if its validity under the state constitution was not." The Court's explanation anchored its analysis in the standard Pullman rule that abstention was appropriate only in instances of "unclear" state law..$^{72}$ To call the state law "clear" in the one instance and "unclear" in the other, though, represented only a conclusory statement, rather than an explication of the doctrine. The Court did not specify why for Pullman purposes it focused narrowly on the challenged action, rather than more broadly on state law as a whole. ${ }^{73}$ Certainly, to the extent the purpose of Pullman abstention is to avoid reaching the federal constitutional question, allowing the state court the opportunity to strike down the challenged action under any state constitutional provision, regardless of its relation to the law directly at issue, would further the goals of the doctrine.

Second, the Supreme Court stated that refusing to abstain for parallel provisions of state constitutions was necessary to prevent abstention from becoming the norm. Because state constitutions often contained broad language mirroring the provisions of the Bill of Rights, abstention based on such provisions would be extremely common. The Court stated: "[T]o hold that abstention is required because [the challenged statute] might conflict with the cited broad and sweeping constitutional provisions, would convert abstention from an exception into a general rule. ${ }^{.74}$ This statement recogmized that the policy of deferring to state courts to clarify state law coexists with a conflicting statutory policy facilitating access to federal courts for asserting federal claims. ${ }^{75}$ Abstention necessarily delays the federal court's adjudication of the federal constitutional issue. ${ }^{76} \mathrm{~A}$ contrary doctrine mandating abstention whenever a state constitution contained a

70. See Flores de Otero, 426 U.S. at 598.

71. See Harris County, 420 U.S. at $84-85 \&$ n.8.

72. See Midkiff, 467 U.S. at 237; Flores de Otero, 426 U.S. at 598; Constantineau, 400 U.S. at 438-39.

73. See Henry J. Friendly, Federal Jurisdiction: A General View 93 n.83 (1973) (noting that the question of the validity of the statute under the state constitution might render state law unclear).

74. Flores de Otero, 426 U.S. at 598; see also Midkiff, 467 U.S. at 237 n.4 (expressing concern about turning abstention into a general rule).

75. See 28 U.S.C. $\$ \S 1331,1343$ (1994).

76. Because of the problem of delay, the Supreme Court has indicated a reluctance to abstain in cases involving voting rights or free speech. See City of Houston v. Hill, 482 U.S. 451, 467-68 (1987) (free speech); Zwickler v. Koota, 389 U.S. 241, 252 (1967) (free speech); Harman v. Forssenius, 380 U.S. 528, 537 (1965) (voting rights); Baggett v. Bullitt, 377 U.S. 360, 379 (1964) (free speech and freedom of association); FRIESEN, supra note 6, at 33; 17 MOORE ET AL., supra note 51, \$ 122.02[3]; see also 17A Charles Alan Wright et al., Federal Practice and Procedure § 4242, at 54-55 \& nn.39-40 (2d ed. 1988) (reporting that harm to important interests caused by delay weighs against abstention). 
broad guarantee of individual rights would threaten to route a large portion of federal constitutional challenges through the state courts. ${ }^{77}$ Indeed, a requireinent of abstention in all cases where relief might be available under a state constitution would threaten to convert abstention into a requirement to exhaust state remedies. Such a broad construction of abstention would erode the fundamental principle that a litigant nnay pursue a federal civil rights action in federal court without first proceeding in state court. ${ }^{78}$

\section{B. Justification for the Doctrine}

This Section further investigates the theoretical underpinnings of the Court's doctrine regarding dual constitutional claims and exposes soine of its latent assumptions. In particular, the Section highlights the Court's premise that state constitutional provisions inerely follow federal doctrine, rather than add imdependent protection for individual rights.

The criteria for abstention articulated by the Court make sense under the Pullman branch of the avoidance doctrine. State court construction of specialized constitutional provisions directly related to a state regulatory scheme might help to sharpen and define the state-law conduct alleged to violate the Federal Constitution. Further, limiting abstention to instances of special constitutional provisions avoids a major judicial modification of the federal court's original federal question jurisdiction. For these reasons, the distinction between constitutional provisions specially related to the challenged statute and unrelated provisions may be coherent, and even normatively attractive as a matter of abstention practice. ${ }^{79}$

77. See FALLON ET AL., supra note 38, at 1240. David Currie has criticized this "too much of a good thing" kind of argument, asserting that the frequency of abstention should not be counted as a reason against its exercise-unless the doctrine itself is suspect and deserving of reconsideration. See David P. Currie, The Supreme Court and Federal Jurisdiction: 1975 Term, 1976 SuP. CT. Rev. 183, 212; see also FRIENDLY, supra note 73, at 93 (questioning doctrine of declining abstention for challenges under provisions of state constitution that mirror Federal Constitution).

78. See McNeese v. Board of Educ., 373 U.S. 668, 672 (1963); Monroe v. Pape, 365 U.S. 167, 183 (1961). Some members of the Court have questioned the wisdom of this aspect of Monroe. See City of Columbus v. Leonard, 443 U.S. 905, 910-11 (1979) (Rehnquist, J., joined by Burger, C.J., and Blackmun, J., dissenting from denial of certiorari).

79. The distinction tracks in some measure Professor Field's analysis of "construction" and "authorization" abstention cases. Situations in which deciding a state-law issue may obviate adjudication of a federal constitutional claim come in two varieties In some instances the challenged law may be unclear and potentially subject to an interpretation that avoids federal constitutional concerns. In other cases, the law at issue may not be subject to limiting construction, but instead may be invalid based on some other state-law authority. In Pullman, for example, the rule requiring white conductors on sleeping cars was clear on its face. The more difficult question was whether the authorizing statute permitted the Commission to promulgate a rule of this kind. In the one case, the key question is what the challenged law means; in the other, the central inquiry is whether the law is authorized. Professor Field has termed these categories "construction" cases and "authorization" cases. Field, supra note 4, at 1101-02. Professor Field has argued further that abstention generally is more appropriate in construction cases, especially when no state conduct has taken place. In these cases, an erroneous interpretation of state law could give rise to a federal constitutional decision that is wholly hypothetical. The federal court effectively would be ruhing on a state law that does not exist. 
The place of the distinction in the larger Siler-Pullman ${ }^{80}$ avoidance doctrine, however, is less clear. The goal of the Siler-Pullman line of cases is to avoid federal constitutional questions when possible and instead to rely on state-law grounds. Pullman's contribution is to allow state, rather than federal, courts to decide close questions of state law. The teaching of Pullman and Siler, then, is that when possible, federal courts should decide the state-law issue first, and if they are not confident in the resolution of the issue, they should allow state courts to answer the question. Because of concerns about delay and impeded access to the federal courts, however, abstention for broad state constitutional provisions paralleling federal provisions may be inadvisable. But what about Siler's suggestion that a federal court should first address pendent state claims so as to avoid unnecessary federal constitutional adjudication? If the federal court does not wish to apply the Pullman branch of the avoidance doctrine in certain cases raising state constitutional issues, then why not go ahead and decide the state constitutional question? Pullman allows federal courts to avoid unclear issues of state law, but if state law is "clear," then Siler suggests that a court should rely on state, rather than federal, constitutional grounds. Yet in Constantineau, Flores de Otero, and Midkiff, where state and federal constitutional provisions mirrored each other, the Court simply reached the federal constitutional claim. The Court did not rely on the alternative state constitutional ground.

One additional aspect of dual constitutional challenges helps both to harmonize these cases with the Siler avoidance principle and to strengthen the Court's Pullman analysis. If the state constitution has the same meaning as the federal, then adjudicating the state constitutional claim would decide, rather than avoid, the federal constitutional question. In other words, if the state constitution is interpreted in lockstep with the federal, then interpretation of the state constitution is effectively interpretation of the Federal Constitution. ${ }^{81}$ In such a case, the federal constitutional

In authorization cases, by contrast, a state actor has definitely performed some action that raises a federal constitutional question. In such situations, the state and federal law provide parallel bases for challenges. The federal constitutional challenge would foeus on state conduct that definitely occurred, even if state law might provide an alternative basis for striking down the conduct. See id. at 1121-22, 1125,1137 n.173. The Court never explicitly embraced this hierarchy of abstention categories, and indeed, in instances such as Pullman itself, clearly contemplated abstention in some authorization cases. Nevertheless, the doctrine that the Court developed in sual constitutional challenges bears some resemblance to the construction/authorization divide. Regulatory schemes involving closely related state constitutional provisions arguably qualify for the construction category. In Harris County, for example, the relevant state constitutional provisions formed an integral part of the local election law. Without an understanding of those articles of the Texas Constitution, the Court feared that it could not address properly the challenge to the election plan.

80. Railroad Comm'n of Texas v. Pullman, 312 U.S. 496 (1941); Siler v. Louisville \& Nashville R.R. Co., 213 U.S. 175 (1909).

81. The Supreme Court's jurisdictional doctrine contemplates that state courts may interpret their constitutions under the influence of the federal model. Under the doctrine of Michigan v. Long, 463 
question cannot be avoided, and Siler has no application. In the 1970s, when the Court was forging its approach to parallel state constitutional challenges, state courts generally did interpret provisions of their state constitutions to mean the same as their federal analogues. ${ }^{82}$ In Constantineau, for example, the relevant provisions of the state constitution apparently had the same meaming as the due process and equal protection clauses of the Fourteenth Amendment. ${ }^{83}$

For similar reasons, the prevalence of lockstep interpretation has provided an additional reason to reject Pullman abstention for parallel state constitutional provisions. Abstention in favor of a lockstep position would effectively invite the state courts to give their interpretation of federal law, and Pullman abstention never has been a device to allow state courts to have the first crack at a federal issue. ${ }^{84}$ In such circumstances, the state constitution offered no haven from federal constitutional adjudication. Abstention would neither avoid the federal constitutional question nor serve the federalism interest of allowing state courts to be the primary expositors of state law. ${ }^{85}$

\section{The Impact of the New Judicial Federalism}

The assumption that state constitutional provisions have the same meaning as their federal analogues helped to buttress the Court's doctrine regarding resolution of dual claims. The growth of independent state constitutional interpretation, however, has undercut this support. ${ }^{86}$ More

U.S. 1032 (1983), unless the state supreme court makes clear that its interpretation of the state constitution is independent of the Federal Constitution, the United States Supreme Court will not treat the state judgment as resting on independent and adequate state-law grounds.

82. See G. Alan Tarr, Constitutional Theory and State Constitutional Interpretation, 22 RuTGERS L.J. 841, 843-44 (1991) (finding lack of reliance on state constitutional guarantees before 1970s); Tarr, supra note 5, at 1111 (same).

83. See Wisconsin v. Constantineau, 400 U.S. 433, 440 n.1 (1971) (Burger, C.J., dissenting).

84. Some have wanted to use Pullman abstention this way. See City of Columbus v. Leonard, 443 U.S. 905, 910-11 (1979) (Rehnquist, J., joined by Burger, C.J., and Blackmun, J., dissenting from denial of certiorari) (" $[\mathrm{T}]$ he time may now be ripe for a reconsideration of the Court's conclusion in Monroe that the "federal remedy is supplementary to the state remedy, and the latter need not be first sought and refused before the federal one is invoked."' (quoting Monroe v. Pape, 365 U.S. 167, 183 (1961))); Constantineau, 400 U.S. at 440 \& n.1 (1971) (Burger, C.J., dissenting) ("[1]t seems to me a very odd business to strike down a state statute ... without any opportunity for the state courts to dispose of the problem either under the Wisconsin Constitution or the U.S. Constitution.") (noting further, that the state constitution had been interpreted to incorporate protections "substantially equivalent" to those in the Federal Fourteenth Amendment); see also Redish, supra note 42, at 109 (arguing that Chief Justice Burger's opinion in Constantineau threatens to convert abstention into a state exhaustion requirement).

85. See Ronald T. Gerwatowski, Of Comity and Common Sense: The Need for Federal Courts to Certify Questions of Unsettled State Constitutional Law, 75 MAss. L. REv. 3, 6 (1990) (noting that abstention was not required for parallel constitutional provisions because of "assumption that the state constitutional analysis is the same as the federal").

86. See Ronald K.L. Collins et al., State High Courts, State Constitutions, and Individual Rights Litigation Since 1980: A Judicial Survey, 16 Publius 141, 141-46 (Summer 1986) (discussing the 
specifically, the increased likelihood that state and federal provisions will receive different constructions forces a clearer articulation of the principles governing abstention for state constitutional claims. To the extent that the Court's holdings have rested on the assumed identity of state and federal provisions, those decisions must be rethought.

If the interpretation of the state and federal constitutional provisions differ, then one of the reasons for rejecting Pullman abstention disappears. Abstention would not invite the state court to opine on the federal constitutional question, but instead would allow the state court to apply its independent interpretation of the state charter, perhaps avoiding the need for the federal court to address the claim under the Federal Constitution. However, abstention would still threaten to route many federal suits through state court. A court would burden a plaintiff's ability to have an expeditious federal hearing on a federal claim by abstaining for broad state constitutional provisions, even if the provisions received interpretation independent of the federal charter. On the other hand, the federal court could follow the lead of Siler and accomplish the goal of avoiding the federal constitutional issue by adjudicating, itself, the state constitutional claim. Because it would avoid the federal constitutional question without the delays attendant to abstention or certification, the Siler approach would seem a strong candidate for revivification. ${ }^{87}$

Independent interpretation of state constitutions thus has eroded the doctrinal foundations undergirding federal courts' resolution of dual constitutional challenges. The Court's practice of adjudicating the federal constitutional claim, rather than deciding the state issue or abstaining, depended on the assumption that the broad state provisions broke no new constitutional ground but instead merely retraced the federal path. Operating under that assumption, the Court could decide the federal constitutional question without impairing any important jurisdictional policy. The Court's doctrine allowed for a speedy resolution of the federal constitutional claim. By resting on federal grounds, the Court did not interfere with the states' abilities to interpret their own law; nor did the Court unnecessarily adjudicate a federal constitutional issue. Because the state constitution had the same meaning as the federal, avoidance of the federal constitutional claim was impossible. The growth of independent state constitutional protections, however, undermines this happy resolution. Now courts must choose among competing goals of vindicating federal

increase in individual rights litigation under state constitutions after the mid-1970s); Ronald K.L. Collins \& Peter J. Galie, Models of Post-Incorporation Judicial Review: 1985 Survey of State Constitutional Individual Rights Decisions, 55 U. CIN. L. REv. 317, 349 (1986) (same); Tarr, supra note 5, at 1112-17 (same).

87. See Lee \& Wilkens, supra note 4, at 340 (suggesting federal court adjudication of state claim as an alternative to Pullman abstention). 
rights, promoting judicial federalism, and avoiding unnecessary federal constitutional adjudication.

\section{III}

\section{The Current Lower Court Treatment of Dual Constitutional Challenges}

Existing doctrine leaves open three principal options for federal courts faced with dual constitutional challenges based on provisions of the state charter that have been interpreted differently from those in the Federal Constitution. First, the court itself may decide the federal constitutional claim. The court could reach this result either by (a) simply refusing to abstain, thus following Constantineau, ${ }^{88}$ Flores de Otero, ${ }^{89}$ and Midkiff, ${ }^{90}$ or (b) decliming to exercise supplemental jurisdiction over the state constitutional claim, a practice finding support in the letter of $\S 1367$ and the spirit of Pennhurst. ${ }^{91}$ Second, following Pullman, ${ }^{92}$ a court could abstain to allow a state court to consider the state constitutional question. Third, reverting to the Siler ${ }^{93}$ tradition, the federal court could itself address the state constitutional claim. Various courts have followed each of these paths, and each has its pitfalls.

\section{A. Option One: Federal Court Decides the Federal Question}

In Guiney v. Roache ${ }^{94}$ the First Circuit adhered to the prior Supreme Court doctrine, despite acknowledging in passing the possibility that the new judicial federalism had undercut that approach. Guiney concerned a challenge to a rule requiring drug testing of Boston Police Departinent employees. The plaintiffs alleged that the requirement violated both the Fourth Amendment and state constitutional protections against unreasonable search and seizure. Without much analysis, the court presumed that the state constitution continued to mirror the federal, despite a developing case law to the contrary. ${ }^{95}$ Relying on that assuinption, the court declined to abstain.

\footnotetext{
88. Wisconsin v. Constantineau, 400 U.S. 433 (1971).

89. Examining Bd. of Eng'rs, Architects and Surveyors v. Flores de Otero, 426 U.S. 572 (1976).

90. Hawaii Hous. Auth. v. Midkiff, 467 U.S. 229, 237 n.4 (1984).

91. Pennhurst State Sch. \& Hosp. v. Halderman, 465 U.S. 89 (1984). Although both altematives entail the immediate adjudication of the federal issue, the different options could lead to quite different results if the court rejects the federal claim. If the court had declined to abstain, the state claim would remain for resolution. If the court instead had declined to exercise supplemental jurisdiction, the plaintiff would be forced to turn to state court for any possible relief.

92. Railroad Comm'n of Texas v. Pullman, 312 U.S. 496 (1941).

93. Siler v. Louisville \& Nashville R.R. Co., 213 U.S. 175 (1909).

94. 833 F.2d 1079 (1st Cir. 1987).

95. See id. at 1083-84; see also Williams v. Lambert, 46 F.3d 1275, 1282 (2d Cir. 1995) (declining to abstain in a situatiou in which "the state might be willing to recognize under its constitution the same rights as the plaintiff claims under the federal Constitution"). For a thoughtful
} 
In accord with the Supreme Court's standard doctrine, the First Circuit felt comfortable assuming that, absent strong evidence to the contrary, the state constitution would follow the federal lead. Therefore, rather than separately addressing the state constitutional claim, the Court of Appeals relied on the federal Fourth Amendment and upheld the drug testing. ${ }^{96}$ In keeping with the growth of the new judicial federalism, however, the assumption that the state constitution would mirror the federal proved false. Subsequently, the Supreme Judicial Court of Massachusetts held that the policy did violate the state constitution. ${ }^{97}$

\section{B. Option Two: Federal Court Allows the State Court to Address the State Claim}

In recognition of the change in circumstances wrought by the new judicial federalism, some courts have abstained to allow state courts to interpret facially parallel state constitutional provisions. In Fields $v$. Rockdale County, ${ }^{98}$ for example, the plaintiffs presented a variety of state and federal constitutional challenges to a county ordinance regulating kennels. The Eleventh Circuit held that abstention was proper to allow a state court to address a claim under the state due process clause. The court acknowledged that the state provision did "mirror the language" of the Federal Constitution. ${ }^{99}$ However, the court emphasized that Georgia courts had construed the state provision to apply more broadly than the federal clause. Because of this divergent interpretation, the court concluded that the kennel ordinance was part of an integrated regulatory scheme that included the state constitutional provisions.

The court's attempt to characterize the state due process clause as part of a specialized regulatory scheme seems a bit forced. In Harris County ${ }^{100}$ and Reetz,${ }^{101}$ the key factor counseling abstention was the close relationship between the challenged statute and the state constitutional provisions. Such a relationship was absent in Rockdale County, where the Georgia due process clause had no special relationship to the kennel ordinance. Despite the court's attempt to shoehorn the case into the integrated regulatory scheme category, the case really concerned a broad state constitutional guarantee and implicated the Supreme Court's concern for abstaining from such provisions. To require abstention for construction of a state due process

\footnotetext{
discussion of the options presented by abstention and Siler, see Cuesnongle v. Ramos, 835 F.2d 1486 (1st Cir. 1987) (declining to abstain).

96. See Guiney v. Roache, 873 F.2d 1557 (1st Cir. 1989).

97. See Guiney v. Police Comm'r, 582 N.E.2d 523 (Mass. 1991).

98. 785 F.2d 1558 (11th Cir. 1986).

99. Id. at 1561 .

100. Harris County Comm'rs Court v. Moore, 420 U.S. 77 (1975).

101. Reetz v. Bozanich, 397 U.S. 82 (1970).
} 
clause, as the court in Rockdale County did, presents the danger of turning abstention into the rule. ${ }^{102}$

A federal district court in the Second Circuit provided a more cogent explanation of its decision to abstain in a case presenting a parallel state constitutional claim. In Hickerson $v$. City of New York, ${ }^{103}$ the plaintiffs challenged a New York City zoning ordinance restricting the location of "adult establishments," including bookstores and theaters that featured sexually explicit material. The plaintiffs asserted that the zoning regulation violated their rights to free expression under both the federal and New York constitutions. Finding that the New York free speech provision contained somewhat different language and had been interpreted to protect more conduct than the First Amendment to the Federal Constitution, the district court abstained. ${ }^{104}$

Hickerson and Rockdale County thus avoid unnecessary federal constitutional adjudication at the cost of routing dual challenges through state court for a determination of the state claim. Victory on the state claim, of course, is by no neans assured. In Hickerson, for example, the New York Court of Appeals rejected the state constitutional challenge. ${ }^{105}$ Indeed, the New York court hewed so closely to federal analysis that the federal courts later held that the plaintiffs were collaterally estopped from litigating the federal issues. ${ }^{106}$

102. In a subsequent case, the Eleventh Circuit emphasized its reluctance to adjudicate state constitutional questions. In Blue Cross and Blue Shield of Alabama, Inc. v. Nielsen, 116 F.3d 1406 (11th Cir. 1997), Blue Cross asserted a state constitutional claim, in addition to state and federal statutory claims. The court made clear its general policy of allowing the state courts to decide the state constitutional questions:

It is even more imperative that any state constitutional law issues in this case be decided by the state supreme court. Given the sensitivity of such matters and how closely they sound to the heart of a state's self-government, a federal court should not purport to hold that a state statute violates the state constitution, except as an unavoidable matter of last resort.

Id. at 1413. Such a statement marks a great distance from Siler, in which the Supreme Court showed little hesitation in deciding a state-law question. The Nielsen opinion is also remarkable for invoking the "last resort" rule for avoiding state constitutional adjudication by a federal court. The last resort rule usually is limited to avoiding federal constitutional questions. See also Cleveland v. Wilken, $917 \mathrm{~F}$. Supp. 794, 797-98 (S.D. Fla. I996) (abstaiming to allow Florida courts to decide if nonresident bond requiremcnt violates state constitution's "open courts" provision).

103. 932 F. Supp. 550 (S.D.N.Y. 1996). The district judge who wrote this opinion is the aunt of the author of this Article.

104. See id. at 555. The case arose in a somewhat unusual posture in that the plaintiffs originally filed in state court, the defendants removed to federal court, and it was the plaintiffs who sought abstention. The court's analysis, though, apparently relied on a more general principle of abstaining whenever an unsettled provision of a state constitution might avoid the federal constitutional decision.

105. See Stringfellow's of New York, Ltd. v. City of New York, 694 N.E.2d 407 (N.Y. 1998).

106. See Hickerson v. City of New York, 146 F.3d 99 (2d Cir. 1998), cert. denied, 119 S. Ct. 795 (1999). Because the plaintiffs initially sought relief in state court, see supra note 104, the Court of Appeals held that the plaintiffs could not reserve their right to litigate federal issues in federal court, see 146 F.3d at 109-12. 


\section{Option Three: Federal Court Decides the State Constitutional Claim}

The Ninth Circuit recognizes the impact of the new judicial federalism by reverting to the Siler model in cases of parallel challenges. In Pue v. Sillas,${ }^{107}$ the Ninth Circuit rejected the notion of abstaining for parallel state constitutional claims. Echoing the Supreme Court's concern with converting abstention from an "exception" into a "general rule," the Ninth Circuit held that abstention based on parallel state and federal constitutional provisions was not proper. ${ }^{108}$ The Pue court read the relevant Supreme Court precedents as allowing abstention only when the state constitutional provision was part of an integrated state statutory scheme. ${ }^{109}$ The court refused to broaden the abstention category to include other cases in which a state constitutional provision might obviate reaching the federal constitutional claim. Building on Pue, later Ninth Circuit cases retained the reluctance to abstain and insisted that federal courts adjudicate parallel state provisions so as to avoid the federal constitutional question. ${ }^{110}$

The Ninth Circuit thus made the move that the Supreme Court never made, not only rejecting abstention for parallel claims, but also resurrecting Siler and resting the holding on state grounds. In the 1994 case Brown v. Woodland Joint Unified School District, ${ }^{111}$ the court reflected critically on this resistance to abstention: "Abstention under Pullman is appropriate where (1) the state's constitution contains a provision unlike any in the Federal Constitution and (2) state court construction of an unclear provision might make federal ruling unnecessary. ... . Both of these conditions are present ...."112 Nevertheless, based on circuit precedent, the court

107. 632 F.2d 74 (9th Cir. 1980).

108. See id. at 81 .

109. See id. at 80 .

110. See, e.g., Carpenter v. City \& County of San Francisco, 93 F.3d 627, 629 (9th Cir. 1996); Vernon v. City of Los Angeles, 27 F.3d 1385, $1391-92$ (9th Cir. 1994); Acton v. Vernonia Sch. Dist., 23 F.3d 1514, 1518 (9th Cir. 1994), vacated, 515 U.S. 646 (1995); Ellis v. City of La Mesa, 990 F.2d 1518, 1522 (9th Cir. 1993); Hewitt v. Joyner, 940 F.2d 1561, 1565 (9th Cir. 1991); Carreras v. City of Anaheim, 768 F.2d 1039 (9th Cir. 1985); see also International Soc'y for Krishna Consciousness v. City of Los Angeles, 966 F. Supp. 956, 958-59 (C.D. Cal. 1997) (applying avoidance principle); Murphy v. Bilbray, No. 90-134 GT, 89-820 GT, 1997 WL 754604, at *9 (S.D. Cal. Sept. 18, 1997) (same); Berkeley Community Health Project v. City of Berkeley, 902 F. Supp. 1084, 1088 (N.D. Cal. 1995) (same), appeal dismissed as moot, 119 F.3d 794 (9th Cir. 1997). When the court fails to follow this practice, it explains the reason for the deviation. See, e.g., American Jewish Congress v. City of Beverly Hills, 90 F.3d 379, 382-83 (9th Cir. 1996) (interpreting state and federal provisions similarly); Harris v. Joint Sch. Dist. No. 241, 41 F.3d 447 (9th Cir. 1994) (asserting that federal constitutional question could not be avoided); Los Angeles County Bar Ass'n v. Eu, 979 F.2d 697, 705 n.4 (9th Cir. 1992) (finding state and federal provisions for right of court access to be "co-extensive"); see also Leventhal v. Vista Unified Sch. Dist., 973 F. Supp. 951, 956 (S.D. Cal. 1997) (Pennhurst doctrine precludes application of avoidance principle).

111. 27 F.3d 1373 (9th Cir. 1994).

112. Id. at 1384. 
declined to order abstention. ${ }^{113}$ The Ninth Circuit thus shows relative comfort in adjudicating state constitutional matters. ${ }^{114}$ In balancing the relevant jurisdictional policies, the Ninth Circuit demonstrates great interest in avoiding federal constitutional questions and in facilitating access to a federal forum for federal rights, but demonstrates little concern for intruding into the interpretation of the state's constitution.

\section{Summary}

Federal courts adopt a variety of approaches in adjudicating dual constitutional challenges. Concerns for allowing state courts to construe state law, avoiding federal constitutional questions, and facilitating access to a federal forum for a federal claim are present in vastly different measures in different opinions. Prior to the new judicial federalism, such policy tradeoffs were not required. The existence of important state rights guarantees, however, forces policy choices. In particular, the interpretation that broad state constitutional provisions grant rights beyond the Federal Constitution has renewed the attraction of abstention, thus posing the risk of diverting all constitutional challenges through state court. The growth of state constitutional protections thus may have the effect of delaying litigants' abilities to vindicate their federal constitutional rights. In addition, the attempt to avoid the state court detour could prove hazardous. Plaintiffs who plead only federal constitutional claims in the federal courts risk the bar of claim preclusion should they later pursue state claims in state or federal court. ${ }^{15}$

113. See id. On the merits, the court found that the challenged school curriculum violated neither the state nor the federal constitutions. See id. at 1385. On the Ninth Circuit's general aversion to abstention, see Jensen v. Yonamine, 437 F. Supp. 368, 380 (D. Haw. 1977) (“The abstention doctrine is not an iron-clad rule. Many courts dislike it; the Ninth Circuit takes a very narrow view of it.").

For a contrasting statement of the proper order in which to address claims, see Friedman v. Board of County Contn''rs, 781 F.2d 777, 780 (10th Cir. 1985) (en banc) ("Because we find the Establishment Clause issue dispositive, we do not address the Free Exercise Clause and New Mexico constitutional claims.").

114. In cases in which the interpretation of the state constitution is genuinely unclear, the Ninth Circuit has indieated a willingness to seek guidance from state courts. While reaffirming its commitment to deciding state constitutional issues first and continuing to resist abstention, a recent Ninth Circuit case invoked California's new certification procedure to allow the California Supreme Court to address a state constitutional question. See Los Angeles Alliance for Survival v. City of Los Angeles, 157 F.3d 1162 (9th Cir. 1998).

115. See, e.g., Nwosun v. General Mills Restaurants, Inc, 124 F.3d 1255, 1258 (10th Cir. 1997), cert. denied, 523 U.S. 1064 (1998) (finding state-law claim precluded where federal court might have asserted supplemental jurisdiction over state claims in previous federal court action); Shaoul $v$. Goodyear Tire \& Rubber, Inc., 815 P.2d 953, 955 (Colo. App. 1990) (holding plaintiff precluded from bringing state-law claims when claims could have been brought in prior federal action); RESTATEMENT (SECOND) OF JUDGMENTS $§ 25 \mathrm{cmt}$. e, illus. 10 (1982).

The availability of attomeys' fees for prevailing plaintiffs in federal civil rights actions, see 42 U.S.C. $\$ 1988$ (1994), provides added incentive for bringing the state claims together with the federal claims. Even if the court rests its decision on state grounds alone, attorneys' fees will generally be awarded as long the federal claim is not wholly "insubstantial." See Carreras v. City of Anaheim, 768 F.2d 1039 (9th Cir. 1985) (awarding $\$ 1988$ fees when plaintiffs prevailed on state constitutional 
Moreover, courts have sometimes suggested that Pullman abstention may be apphed even when the parties do not themselves invoke state law. ${ }^{116}$

The Ninth Circuit avoids the risk of general detour by taking an active role in interpreting state constitutions. The next Part defends that decision by adding an element not considered by the courts. The opinions do not analyze whether the structural features of the federal courts might render them particularly appropriate forums for state constitutional claims; not even the Ninth Circuit focuses on the special characteristics of the federal courts. Drawing on the models of federal court treatınent of diversity and federal constitutional claims, I examine how federal adjudication of state constitutional claims might represent a desirable instance of crossfertilization, rather than a necessary evil. The next Part offers an alternative vision of the role of federal courts in our federalist system, suggesting, contrary to some of the implications of Pennhurst and Pullman, that federal courts can play a valuable role in the development of state constitutional law.

IV

The Myth of STATE Court SUPERIORITY?

Because state courts are the authoritative interpreters of state law, courts and commentators generally agree that state courts provide superior forums for state-law claims, including state constitutional claims. ${ }^{117}$ Federal adjudication of supplemental state-law claims is tolerated for reasons of efficiency and judicial administration. Allowing federal courts to exercise supplemental jurisdiction over state claims prevents plaintiffs from being forced to split their claims between state and federal forums and may

claims); FRIESEN, supra note 6, at 571-79; cf. Hagans v. Lavine, 415 U.S. 528, 537 (1974) (deseribing substantial claim as one that is not "obviously frivolous"). Even if a federal court certifies a state-law question to a state tribunal and the plaintiff receives a favorable ruling in state court, the plaintiff can recover attorneys' fees in federal court. See Exeter-West Greenwich Reg'1 Sch. Dist. v. Pontarelli, 788 F.2d 47 (1st Cir. 1986) (holding plaintiff entitled to attorneys' fees because state-law claims involved same nucleus of operative facts as federal claims).

116. See, e.g., Rcid v. Board of Educ., 453 F.2d 238, 242 n.7 (2d Cir. 1971) (expressing concern that important policy interests would be thwarted if plaintiff could avoid abstention by failing to plead state claim); see also Zwickler v. Koota, 389 U.S. 241, 257 (1967) (Harlan, J., concurring) (same); RR Village Ass'n v. Denver Sewer Corp., 826 F.2d 1197, 1207 (2d Cir. 1987) (Van Graafeiland, J., dissenting) (same). In addition, a court may invoke Pullman abstention, even if not rcquested by the parties. See WRIGHT ET AL., supra note 76, § 4243, at 62-64.

117. Professor Field has summarized this theory as follows:

In a system in which federal courts are the final authority on questions of federal law and state courts are final on questions of state law, but where the two legal systems are often intertwined in a particular case, prior allocation to the state or federal forum would logically (except where there is some competing interest at stake) be made according to the probability that a particular forum's law will be the more important to the disposition of the controversy. Field, supra note 4, at 1084-85 (footnotes omitted). 
permit the federal court to avoid a federal constitutional ruling. ${ }^{118}$ From this perspective, federal adjudication of state law is at best a necessary evil.

In certain other contexts, by contrast, the federal court is generally considered the preferable forum. With regard to federal constitutional claims in particular, scholars have argued that federal courts provide superior adjudication. The assumption of federal superiority, however, is not limited to federal claims. Diversity jurisdiction functions on the premise that federal courts should sometimes be available to hear pure state-law claims. Diversity jurisdiction places a state claim in a federal forum not because of the federal company it keeps, but because of the nature of the parties and the forum. The availability of diversity jurisdiction reflects the judgment that litigants in certain kinds of cases should be allowed to choose a federal forum for the resolution of their state claim, either to avoid local bias or to take advantage of the alleged structural superiority of the federal courts.

This Part discusses whether the constitutional or diversity paradigms may be applicable to supplemental state constitutional claims. Do situations exist in which federal courts may be superior forums for the adjudication of state constitutional claims? Even before Erie Railroad Co. $v$. Tompkins, ${ }^{119}$ it was clear that federal courts must follow applicable state court interpretations of state constitutions. ${ }^{120}$ Federal courts might nevertheless play a valuable role $\mathrm{m}$ developing and applying state constitutional law. I examine, in turn, some of the reasons for favoring federal courts in federal constitutional and diversity cases, and discuss their applicability to state constitutional litigation.

118. See Friedenthal ET AL, supra note $53, \S 2.12$, at 69 ; see also supra note 53 (citing sources).

119. 304 U.S. 64 (1938).

120. See Green v. Neal's Lessee, 31 U.S. (6 Pet.) 291 (1832). But see Township of Pine Grove v. Talcott, 86 U.S. 666, 677 (1873) (refusing to follow Michigan Supreme Court's ruling that statute authorizing issuance of bonds was unconstitutional); Gelpcke v. City of Dubuque, 68 U.S. (1 Wall.) 175 (1863) (refusing to follow highest state court's inost recent construction of its constitution). Gelpcke could be understood as applying the Contracts Clause of the Federal Constitution, but the case seems to contemplate a federal court's rejecting a state court's interpretation of its constitution, even if the state decision violates no provision of the Federal Constitution. See Gelpke, 68 U.S. at 206-07 ("We shall never immolate truth, justice, and the law, because a State tribunal has erected the altar and decreed the sacrifice."); David P. Currie, The Constitution in the Supreme Court: Contracts and Conmerce, I836-1864, 1983 Duke L.J. 471, 494; Jan G. Deutsch, Property, the Individual, and Governmental Power: The Meaning of Gelpcke v. City of Dubuque, 4 J. CoRP. L. 357, 362-75 (1979) (discussing background and significance of Gelpcke); William H. Rand, Jr., Swift v. Tyson versus Gelpcke v. Dubuque, 8 HaRv. L. Rev. 328, 343-48 (1895); Suzanna Sherry, Correspondence, The Eleventh Amendment and Stare Decisis: Overruling Hans v. Louisiana, 57 U. CHI. L. REv. 1260, 1266 (1990). 


\section{A. Structural Protection}

The "parity" debate, concerning whether state and federal courts are equally suitable venues for the adjudication of federal constitutional claims, has long been a mainstay of the federal courts literature. Commentators arguing for the "disparity" position cite various reasons why state courts might be less hospitable to individual rights claimants. The structural protection for federal judges embodied in Article III of the Federal Constitution figures prominently in these debates. ${ }^{121}$ The constitutional guarantee of life tenure with undiminished salary affords federal judges a measure of protection from political pressures that most state judges do not enjoy. ${ }^{122}$ Most state judges are elected or subject to periodic retention elections. ${ }^{123}$ Long terms or nonpartisan elections may confer some measure of political insulation on state judges, ${ }^{124}$ but less than that afforded by Article III. ${ }^{125}$ Because constitutional claims often pit individuals against majority decision makers, insulation from majoritarian pressures is thought to be important for fair adjudication of constitutional claims. Indeed, the concept of politically accountable judges conflicts with constitutionalism's fundamental commitment to protect certain decisions from current majoritarian impulses. ${ }^{126}$ To be sure, the results of Presidential elections may change the

121. See Thomas J. Maroney \& Daan Braveman, "Averting the Flood": Henry J. Friendly, the Comity Doctrine, and the Jurisdiction of the Federal Courts-Part II, 31 SyRACUSE L. Rev. 469, 508-10 (1980) (noting federal courts' greater structural independence); Neuborne, supra note 26, at 1127-28 (same); Martin H. Redish, Reassessing the Allocation of Judicial Business Between State and Federal Courts: Federal Jurisdiction and "The Martian Chronicles", 78 VA. L. REv. 1769, 1779-80 (1992) (same); Michael Wells, Is Disparity a Problem?, 22 Ga. L. REv. 283, 300 (1988) (same). For a discussion of state courts' treatment of federal rights in the death penalty context, see Ronald F. Wright \& Marc Miller, In Your Court: State Judicial Federalism in Capital Cases, 18 URB. LAw. 659 (1986).

122. The structural protections of Article III do not necessarily make federal judges apolitical, but they do afford federal judges a measure of political independence. See RICHARD A. POSNER, THE FEDERAL CourTs: Crisis AND ReForm 16-17 (1985) (discussing how independence makes the federal court system an "autonomous center of power").

123. See 31 Council of State Governments, The Book of the States 133-35 (1996) (describing selection and retention methods of state judges); Polly J. Price, Selection of State Court Judges, in State Judiciaries and ImPartiality: Judging the Judges 9-38 (Roger Clegg \& James D. Miller eds., 1996) (analyzing different methods of judicial selection).

124. See Erwin Chemerinsky, Federal Courts, State Courts, and the Constitution: A Rejoinder to Professor Redish, 36 UCLA L. Rev. 369, 371 (1988); see also Jonathan P. Nase, The Governor's Impact on an Elected Judiciary: The Lessons from Pennsylvania, 69 TEMPLE L. REv. 1137 (1996) (discussing different models of judicial selection and noting role of gubernatorial appointment even in elective system).

125. Cf. J. Mark Ramseyer, The Puzzling (In)dependence of Courts: A Comparative Approach, 23 J. LEGAL STUD. 721 (proposing theory as to which polities will create independent judiciaries).

126. See Stephen L. Carter, Does Democracy Threaten Jidicial Independence, in Preserving the lndependence of the Judiciary: The Dual Challenge of Democracy and the Budget Crisis 37, $37-40$ (Roscoe Pound Foundation 1993); Stephen B. Bright, Can Judicial Independence be Attained in the South? Overcoming History, Elections, and Misperceptions About the Role of the Judiciary, 14 GA. ST. L. REv. 817, 844-52 (1998); Erwin Chemerinsky, Evaluating Judicial Candidates, 61 S. CAL. L. Rev. 1985, 1987-88 (1988) (arguing that electoral review of judges threatens the rule of law); Steven P. Croley, The Majoritarian Difficulty: Elective Judiciaries and the Rule of 
composition of the federal courts in one direction or another, but the majoritarian problem of most state courts remains relatively constant and in continuing systematic tension with individual rights enforcement. ${ }^{127}$ Recent trends toward increased politicization of state judicial elections are likely to increase the majoritarian pressures. ${ }^{128}$

Scholars rejecting the parity of state courts further argue that federal judges may have greater psychological affmities with constitutional plaintiffs. ${ }^{129}$ State judges may well have more frequent contact with the state and local government actors, such as police officers, who are defendants in constitutional litigation, as well as with the lawyers who represent these

Law, 62 U. ChI. L. Rev. 689 (1995) (same); Martin H. Redish, Judicial Parity, Litigant Choice, and Democratic Theory: A Comment on Federal Jurisdiction and Constitutional Rights, 36 UCLA L. REV. 329, 333-34 (1988) (arguing that state judges' political accountability creates a potential for biased adjudication); Redish, supra note 121, at 1781 (same). Professor Redish has suggested that the lack of structural safeguards ensuring state court independence might even violate the federal constitutional guarantee of due process See Martin H. Redish \& Lawrence C. Marshall, Adjudicatory Independence and the Values of Procedural Due Process, 95 YALE L.J. 455 (1986); see also Scott D. Wiener, Note, Popular Justice: State Judicial Elections and Procedural Due Process, 31 HARV. C.R.-C.L. L. REV. 187, 202-204 (1996) (arguing that judicial elections violate due process); Larry W. Yackle, Choosing Judges the Democratic Way, 69 B.U. L. REv. 273 (1989) (discussing potential constitutional standards for judicial selection). For a recent discussion of current views of judicial independence, see Symposium Judicial Review and Judicial Independence: The Appropriate Role of the Judiciary, $14 \mathrm{GA}$. ST. L. REv. 737 (1998).

127. See Neuborne, supra note 4, at 799 (asserting continuing validity of disparity arguments despite Republican judicial appointments); Wells, supra note 121, at $300 \mathrm{n} .84$ (same).

128. See Croley, supra note 126, at 735 (noting increasing salience of state judicial elections); Susan Beck, Justice on the Run, AM. LAw., Sept. 1998, at 76 (describing contested judicial retention election in California in November 1998); Gerald F. Uelmen, Crocodiles in the Bathtub: Maintaining the Independence of State Supreme Courts in an Era of Judicial Politicization, 72 Notre DAME L. REv. 1133 (1997); Peter D. Webster, Selection and Retention of Judges: Is There One "Best" Method?, 23 FLA. ST. U. L. REv. 1, 19 (1995) (discussing increasingly contested nature of judicial elections and potential effect on democratic accountability of judges); John Gibeaut, Taking Aim, A.B.A. J., Nov. 1996, at 51 (noting increasing salience of state judicial elections); Edmund V. Ludwig, Another Case Against the Election of Trial Judges, PA. LAw, May/June 1997, at 33, 33 (same); James Podgers, Balancing the Equation, A.B.A. J., Feb. 1999, at 84-85 (same); Loren Singer, Nebraska, Kentucky, Texas Jurists Lose Their Seats in Nov. 5 Elections, WEST's LEgAL NEws, Nov. 12, 1996, at 12064; see also Victoria Slind-Flor, Justices Feud in Wash. State, NAT'L L.J., June 15, 1998, at A1, Al, A19 (describing increasingly partisan atmosphere on Washington Supreme Court and increasingly contested partisan elections); Jackson Williams, Irreconcilable Principles: Law, Politics, and the Illinois Supreme Court, 18 N. ILL. U. L. REv. 267 (1998) (discussing increased politicization of Illinois Supreme Court). Increased political pressure also has been brought against federal judges. See Edward Hartnett, Why is the Supreme Court of the United States Protecting State Judges from Popular Democracy?, 75 TEx. L. REv. 907, 975-76 (1997); Ludwig, supra, at 33-34; see also Chemerinsky, supra note 124, at 372 (asserting that federal judges, who live in same community and may desire higher judicial office, may be subject to same pressures as state judges). But cf. Chemerinsky, supra note 126, at 1991 ("Admittedly, a judge who faces a certain retention election has more incentive to be influenced than a federal judge who has only a relatively small chance of elevation to a higher court.").

Selection by appointment, rather than by popular election, may entail political pressure as well. See Representative Views, in PREserving THE INDEPENDENCE OF THE Judiciary, supra note 126, at 14, 14-21 (quoting views of unnamed state judges). Relatively short terms in office, however, exacerbate the political pressures on state judges.

129. See Neuborne, supra note 26 , at 1124-27; Wells, supra note 121 , at 300 . 
officials. This familiarity may incline state judges to feel greater sympathy for those on the defendants' side in constitutional cases. In instances of repeated abuse, familiarity may breed contempt. However, in the more common situations in which violations turn on finer points of constitutional law, ${ }^{130}$ state judges may favor the officials with whom they interact on a day-to-day basis. ${ }^{131}$ More generally, state judges may feel greater allegiance to the political system with which they are most closely identified. ${ }^{132}$

The premises of the various positions in the parity debate are difficult to verify. Empirical comparisons of state and federal courts have been largely inconclusive, and it is far from clear that the controversy is subject to empirical resolution..$^{133}$ Nevertheless, scholars appear to have arrived at a consensus that federal courts are more receptive than state courts to claims of individuals under the Federal Constitution. ${ }^{134}$ Certainly, litigants often assume that federal courts will provide a more hospitable forum for individuals. ${ }^{135}$ Moreover, while direct comparisons of state and federal courts have contribuited little useful information to the debate, comparative studies of state courts have produced some relevant findings. While the evidence is conflicting, recent studies of state courts have suggested that the

130. See, e.g., infra Part IV.F (discussing litigation over erosses on public property).

131. I am grateful to my colleague William W. Buzbee for suggesting this "repeat player" perspective on the parity debate.

I32. See Paul Chevigny, Section 1983 Jurisdiction: A Reply, 83 HaRv. L. ReV. 1352, 1358-60 (1970).

133. Some scholars have sought to prove the parity of state and federal courts through empirical testing. See Michael E. Solimine \& James L. Walker, Constitutional Litigation in Federal and State Courts: An Empirical Analysis of Judicial Parity, 10 Hastings ConST. L.Q. 213 (1983); Michael E. Solimine \& James L. Walker, State Court Protection of Federal Constitutional Rights, 12 HARV. J.L. \& PuB. PoL'y 127 (1989). Others, though, have pointed out the flaws in sueh empirical efforts. See Erwin Chemerinsky, Parity Reconsidered: Defining a Role for the Federal Judiciary, 36 UCLA L. Rev. 233, 256-273 (1988); see also YACKLE, supra note 23, at 12 (discussing difficulty in resolving parity debate empirically); Ann Althouse, Tapping the State Court Resource, 44 VAND. L. REv. 953, 958-59 (1991) (discussing difficulty in resolving parity debate); Neuborne, supra note 4, at 798 ("[I]t has been impossible to resolve the [parity] dispute empirically....").

134. As one commentator expressed it:

Although the Court refuses to say so, nearly everyone else would agree that there are differences in the performance of state and federal courts. As between the two, state eourts are more likely to decide close questions in constitutional cases in favor of the state, while federal eourts will more often decide them in favor on the individual asserting a constitutional claim.

Wells, supra note 121, at 335-36; see also Michael Wells, Behind the Parity Debate: The Decline of the Legal Process Tradition in the Law of Federal Courts, 71 B.U. L. Rev. 609, 610-I1 (1991) (finding general consensus that state courts provide eonstitutionally adequate hearings on federal claims, but that outcomes in state and federal courts differ systemically).

135. See Neuborne, supra note 4, at 799-800; Redish, supra note 121, at 1826. But cf. id. at 1826 n.302 ("Today, given the increasing political and constitutional conservatism of the federal courts, it is certainly conceivable that, at least in certain areas, a civil rights plaintiff would prefer a state forum."). 
degree of political insulation does have an impact on judicial rulings; ${ }^{136}$ these studies support the conclusion that minority groups fare better in courts with greater political independence. ${ }^{137}$

The same factors that make federal courts attractive forums for the adjudication of federal constitutional claims also would seem to apply in the context of state constitutional litigation. ${ }^{138}$ Like federal constitutional claims, state constitutional claims generally represent minority challenges to majority decisions. The relative lack of political insulation may incline state courts to underprotect the rights of unpopular minorities. ${ }^{139}$ State and federal constitutional claims do, of course, raise somewhat distinct concerns. State judges might be especially hesitant to enforce federal law against the state, the entity to which the judge has an institutional

136. See Daniel R. Pinello, The Impact of Judicial-Selection Method in State-SupremeCourt Policy: Innovation, Reaction, AND Atrophy 130 (1995) ("[T]he data here show the conventional wisdom of the 1980s among professional political scientists that selection method has no meaningful impact on judicial policy is mistaken."); Peter M. Shane, Interbranch Accountability in State Govermment and the Constitutional Requirement of Judicial Independence, 61 LAW \& CONTEMP. ProBs. 21, 52 (1998) ("Substantial evidence supports the proposition that the method of selection significantly affects judicial behavior-especially judicial willingness or unwillingness to uphold unpopular individual interests...."); Paul Albert Kramer, Analyzing the Determinants of State Constitutional Activism: A Search for State Court Independence in the American Federal System 15863, 206-07 (1995) (unpublished Ph.D. dissertation, University of Minnesota) (on file with the Emory University Law Library) ("States with either a merit-based appointment system or direct judicial appointment produce state courts that are more activist relative to courts in states where justices face electoral reprisal."); see also Susan P. Fino, The Role of State Supreme Courts in the New Judicial Federalism 116-17 (1987); Melinda Gann Hall, Electoral Politics and Strategic Voting in State Supreme Courts, 54 J. PoL. 427, 442 (1992) (concluding that judicial elections have an impact on judges' votes in cases) [hereinafter Hall, Electoral Politics]; Melinda Gann Hall, Justices As Representatives: Elections and Judicial Politics in the American States, 23 AM. PoL. Q. 485 (1995) (finding that elections influence judges' votes in death penalty cases). But see Jona Goldschmidt, Merit Selection: Current Status, Procedures, and Issues, 49 U. Mrami L. Rev. 1, 43-45 (1994) (reporting studies fimding little connection between selection method and judicial decisions). The more basic issue of the relative importance of insulation as opposed to accountability is largely a normative question that does not lend itself to empirical resolution. See Philip L. Dubois, From Ballot to Bench: Judicial ElECTIONS AND THE QUEST FOR ACCOUNTABILITY 27-28 (1980).

137. See FINO, supra note 136, at 116-17 ("lt is no accident that the most civil libertarian courts in this study, California and New Jersey, are also the states with the longest terms of office for their supreme court justices."); PINELLO, supra note 136, at 136 ("[P]olitically and/or economically powerless groups ... will most likely prevail in jurisdictions with pure appointive-selection systems.").

138. See Michael E. Solimine \& James L. Walker, Federalism, Liberty, and State Constitutional Law, 23 Orio N.U. L. Rev. 1457, 1464-66 (1997) (noting applicability of parity arguments to state constitutional interpretation by state courts); Solimine \& Walker, State Court Protection of Federal Constitutional Rights, supra note 133, at 151 (same).

139. See Redish, supra note 121 , at 1781 . Ensuring the political accountability of judges might have certain benefits. See Representative Views, in PRESERving THE INDEPENDENCE OF THE JUDICIARY, supra note 126, at 17, 17-21 (quoting views of unnamed judges supportive of elective system). Political accountability also has definite costs. See id. (quoting views of unnamed judges critical of elective system). The main point for present purposes is that political accountability is likely to incline judges to favor majority over minority interests. See Hall, Electoral Politics, supra note 136, at 442-43 (presenting study showing that judicial elections incline judges to adopt positions held by popular majorities). 
allegiance. State constitutional claims, which require the judge to apply only laws that emanate from the state, would not trigger such hesitation. State constitutional litigation does not require the state court to invalidate state action because of the commands of another sovereignty. Nevertheless, state judges may be reluctant to enforce the claims of unpopular groups or individuals against state actors. ${ }^{140}$ In sum, the very same insulation from political considerations that enables federal judges to make unpopular decisions regarding federal constitutional rights without fear of reprisal allows them to make unpopular decisions regarding state constitutional rights as well. ${ }^{141}$

\section{B. The Diversity Model of Supplemental Jurisdiction}

One key difference between state and federal adjudication of state constitutional provisions is the state court decision's claim to inherent validity. In one sense, the decision of the state court, as reviewed through the state appellate system, defines the contour of the state constitutional right. In this view, it is paradoxical to speak of state courts as underprotecting the rights of individuals, for it is the state courts that establish the breadth of the right. Disparity between the state and federal courts thus necessarily evidences error by the federal tribunal. The example of diversity jurisdiction, however, presents an alternative perspective.

Debates over diversity jurisdiction often focus on the relative merits of the state and federal judiciaries. Though the original purposes of diversity jurisdiction remain subject to dispute, ${ }^{142}$ one prominent rationale was, and is, the need to protect outsiders against bias from local state judges. ${ }^{143}$ Politically insulated federal judges, perhaps endowed with a more national perspective, were expected to provide a fairer hearing for disputes involving parties from different states. ${ }^{144}$ The availability of the federal judiciary

140. See Redish, supra note 121 , at $1825-26$ (noting difference in "systemic allegiance" of state and federal judges).

141. Unpopular minorities come in many forms. At the time of the Framing, creditors constituted an unpopular minority, and the federal courts were designed in part to protect this group. See Wythe Holt, 'To Establish Justice': Politics, the Judiciary Act of 1789, and the Invention of the Federal Courts, 1989 DuKE L.J. 1421, 1453-66. To the extent constitutionalism entails removing ccrtain judgments from the control of current popular majorities of whatever sort, judicial insulation promotes constitutionalism. But cf. Michael J. Klarman, What's So Great About Constitutionalism?, 93 Nw. U. L. REV. 145, 160-63 (1998) (presenting positive and normative criticism of conception of constitutionalism as protecting minority rights).

142. See WRIGHT, supra note 40, at 142-43; Redish, supra note 121 , at 1800 .

143. See 13B WRIGHT ET AL., supra note 76, § 3601; see also Friedman, supra note 17, at 541 (citing bias against out-of-state litigants as justification for diversity jurisdiction).

144. See WILfRed J. RITZ, Rewriting the History of The Judiciary Act of 1789, at 66 (Wythe Holt \& L.H. LaRue eds., 1990); John P. Frank, Historical Bases of the Federal Judicial System, 13 LAW \& CONTEMP. PRoBs. 3, 22-28 (1948); Neuborne, supra note 26, at $1128 \mathrm{n} .83$; Robert J. Pushaw, Jr., Article III's Case/Controversy Distinction and the Dual Functions of Federal Courts, 69 Notre DAME L. REV. 447, 507 (1994). 
was meant to counteract the potential for systematic bias against outsiders. ${ }^{145}$ Before Erie, diversity jurisdiction also provided federal judges with an opportunity to create a uniform national common law, a kind of "general law" that could provide an alternative in light of the perceived inferiority of a particular state's law. ${ }^{146}$ After Erie, it is clear that the law applied in the state and federal courts should be the same. ${ }^{147}$ Nevertheless, the perceived need for a more impartial tribunal continues to provide the key justification for diversity jurisdiction. ${ }^{148}$ State and federal courts are different, ${ }^{149}$ and diversity jurisdiction recogmizes that these differences may make the federal forum more suitable for the adjudication of a particular state-law claim, even if the governing law remains the same..$^{150}$ Though state and federal courts are bound to follow the same law, their important responsibilities for adjudicating myriad legal issues and supervising the fact-finding process may endow the choice between the two systems with great significance. ${ }^{\text {I5t }}$

For reasons similar to those that justify diversity jurisdiction, supplemental jurisdiction over state constitutional claims could allow a federal court to provide a more impartial reading of the state constitution. ${ }^{152}$ State constitutional claims may pose dangers of bias against outsiders, though here defined by political or social rather than by geographical criteria. Indeed, one of the common criticisms of the bias rationale for diversity jurisdiction lies in its underinclusion. Commentators assert that the most common forms of bias confronting litigants in contemporary society rest on race or class, rather than state citizenship. ${ }^{153}$ The plaintiffs in state constitutional cases nay well be subject to such bias.

145. See Holt, supra note 141, at 1453-66.

146. See Henry J. Friendly, The Historic Basis of Diversity Jurisdiction, 41 HARv. L. REv. 483, 495-97 (1928); Patrick J. Borchers, The Origins of Diversity Jurisdiction, the Rise of Legal Positivism, and a Brave New World for Erie and Klaxon, 72 TEX. L. REv. 79, 132 (1993); see also RITZ, supra note 144, at 79 ("It would have literally been unthinkable for the members of the First Congress to have directed national courts sitting in diversity to apply the law of the states in which they sat.").

147. Some continue to question the wisdom of the Erie holding. See Borchers, supra note 146.

148. See FRIENDLY, supra note 73, at 146; John Frank, The Case for Diversity Jurisdiction, 16 HARv. J. ON LegIs. 403, 409-10 (1979); Lany Kramer, Diversity Jurisdiction, 1990 BYU L. Rev. 97 , 119-20.

149. See Hazard, supra note 25 , at 647 (listing institutional differences between state and federal courts and suggesting that such differences are "synergistically, systematically, and ubiquitously "outcome determinative" ").

150. See IVells, supra note 121 , at 329 .

151. See England v. Louisiana State Bd. of Med. Exam'rs, 375 U.S. 411, 416 (1964) (noting importance of availability of federal trial court); $c f$. Wells, supra note 121, at 325 ("In cases where the substantive rule is not clear and the trial court must construe it, or where the substantive rules must be applied to a set of facts, or where the facts themselves are in dispute, the attitudinal differences [between state and federal courts] may prove critical.").

152. $C f$. Redish, supra note 121 , at 1828 (noting difference between deference to state law and deference to state courts in context of adjudication of federal rights).

153. Almost thirty years ago, the authors of the American Law Institute study on federal jurisdiction expressed the sentiment as follows: 
The possibility of "cross-pollination" between the state and federal judicial systems constitutes another benefit often attributed to diversity jurisdiction. ${ }^{154}$ Federal judges sitting in diversity may provide valuable contributions to the development of state law. Federal opinions will never be the last word on the content of state law (except for the litigants in a particular case), but they may offer significant additional perspectives on complex problems. Similar to their role in diversity litigation, federal courts could contribute to the development of state constitutional law through their decisions on supplemental state constitutional claims. ${ }^{155}$ Enriched by their experience in interpreting the Federal Constitution, federal judges may well have valuable insights to add to the development of state constitutional law.

Federal courts could assist in the percolation of state constitutional issues in a manner not possible within a state judicial system. The United States Supreme Court often allows issues to percolate in various circuits and in various states before it chooses to resolve the matter. ${ }^{156}$ When the Court does reach the question, it can benefit from the views expressed and the experiences gained in the various court systems. ${ }^{157}$ The percolation

[A]s to the matter of prejudice, the conventional justification for general diversity jurisdiction, none of the significant prejudices that beset our society today begins or cnds when a state line is traversed.... [T] here are prejudices on racial, religious, economic and other grounds that affect the administration of justice in actions between co-citizens as much as in those involving an out-of-stater.

American Law Institute, Study of the Division of Jurisdiction Between STATE and Federal Courts 106 (1969); see Kramer, supra note 136, at 120 ("It seems clear today that many othcr types of bias are far more prevalent today and far more likely to influence litigation than bias against citizens of other states."); Neuborne, supra note 26, at $1128 \mathrm{n} .83$ (noting danger of bias outside of diversity configuration); Redish, supra note 121, at 1800-01; Herbert Wechsler, Federal Jurisdiction and the Revision of the Judicial Code, 13 LAw \& CONTEMP. PROBS. 2I6, 236 (I948) ("It is, indeed, a rather startling thought that this least troublesome of all the prejudices [against out-of-state litigants] should be the basis of a special federal forum which none of the hostilities that flow from faction, interest, race, or creed is deemed sufficient to provide."); see also Chevigny, supra note 132, at 1358 (noting state court bias as rationale for federal jurisdiction in both diversity and federal civil rights cases).

154. See PosNER, supra note 122, at 144-45 (noting federal court contribution to developmcnt of state law); William M. Landes \& Richard A. Posner, Legal Change, Judicial Behavior, and the Diversity Jurisdiction, 9 J. LEGAL STud. 367, 386 (1980) (same); Redish, supra note 121, at 1773 (noting benefits of "intersystemic cross-pollination"); David L. Shapiro, Federal Diversity Jurisdiction: A Survey and a Proposal, 91 HARv. L. Rev. 317, 324-27 (1977) (noting federal court contribution to development of state law); Geri J. Yonover, A Kinder, Gentler Erie Reining in the Use of Certification, 47 ARK. L. REv. 305, 325-26 (1994) (discussing notion that "fcderal court ascertainment of state law, even if subsequently proven wrong, has a positive, normative effcct on the development of state law"); id. at 337-39 (noting benefits of cross-pollination).

155. Professor Redish has summarized this point as follows: "One of the supposed benefits of federal judicial interpretation of state law is the 'cross-pollination' between the state and fcderal judicial systems. This function would seem to be as important in cases of supplemental jurisdiction as in those in which diversity jurisdiction is exercised." 16 MOORE ET AL., supra note 5I, § 106.64.

156. See Todd J. Tiberi, Supreme Court Denials of Certiorari in Conflicts Cases: Percolation or Procrastination?, 54 U. PITT. L. REv. 861 (1993) (critically discussing "percolation" theory).

157. See Samuel Estreicher \& John E. Sexton, A Managerial Theory of the Supreme Court's Responsibilities: An Empirical Study, 59 N.Y.U. L. REv. 681, 699 n.68, 716 (1984) (discussing 
process allows the Court to collect a great deal of information before it propounds a rule that will bind the entire nation. In like manner, state courts and lower federal courts have engaged in useful dialogue over the interpretation of the Federal Constitution. Professors Cover and Aleinikoff, in particular, have documented the value of such a dialogue in the context of federal habeas corpus review of state convictions. ${ }^{158}$ Their work demonstrates that the different institutional perspectives of state and federal judges make this dialogue especially productive. ${ }^{159}$ In most state systems, such percolation cannot occur. States normally have a unitary appeals system; once the intermediate state court decides the matter, the ruhing will bind all other courts in the state unless and until it is overruled by the highest state court. The federal courts could provide an additional source of percolation, and their different institutional perspective would add an important element to the dialogue that is missing even in state court systems that are divided into different judicial districts or departments.

To be sure, other commentators have criticized diversity jurisdiction precisely because it invites unwanted and non-authoritative federal "contributions" to state law. ${ }^{160}$ To the extent one believes that state constitutional law reflects the unique values and experiences of the state community, federal judges might appear ill-equipped for the interpretative task. ${ }^{161}$ As I have explained elsewhere, though, I believe the text and structure of the state constitution, rather than the distinctive history of the state, should provide the focus of interpretation. ${ }^{162}$ Federal judges are certainly quite adept at such textual and structural approaches. Nor are federal judges generally unfamiliar with state law. Normally, federal district judges have direct experience practicing law in the state in which they sit. ${ }^{163}$ Because they usually will have practiced in at least a nearby state,

benefits of percolation); J. Clifford Wallace, The Nature and Extent of Intercircuit Conflicts: A Solution Needed for a Mountain or a Molehill?, 71 CALIF. L .REv. 913, 927 n.66, 929 (1983) (same).

158. See Robert M. Cover \& T. Alexander Aleinikoff, Dialectical Federalism: Habeas Corpus and the Court, 86 YALE L.J. 1035 (1977); see also Wright \& Miller, supra note 121, at 687-94 (documenting dialogue between federal and state courts in capital cases).

159. See Cover \& Aleinikoff, supra note 158, at 1048-51.

160. See Bassler \& Potenza, supra note 44, at 517-20; Kramer, supra note 136, at 104-06 \& n.42; Sloviter, supra note 48, at 1681-87; see also Collins \& Galie, supra note 86 , at 347 (in context of supplemental jurisdiction, noting "specter of lower federal court judges rendering unreviewable state law-based judgments which carry a certain precedential, or at least persuasive, value").

161. See Sloviter, supra note 48 , at $\mathbf{1 6 8 2}$ (arguing that a federal judge "who may not even be a citizen of the state involved, is certainly not likely to be as attuned as a state judge is to the nuances of that state's history, policies, and local issues").

162. See Robert A. Schapiro, Identity and Interpretation in State Constitutional Law, 84 VA. L. REv. 389, 440-56 (1998).

163. See Dan T. Coenen, To Defer or Not to Defer: A Study of Federal Circuit Deference to District Court Rulings on State Law, 73 MiNN. L. REv. 899, 905 (1989) (discussing state-law expertise of federal district judges). 
judges sitting on the court of appeals may have experience in the laws of a particular state as well.

Moreover, the benefits of cross-pollination run in both directions. Adjudicating state constitutional claims would enrich federal courts' understanding of the Federal Constitution, as state precedents could provide a valuable comparative perspective on constitutional issues. Recent opmions of the United States Supreme Court show increasing interest in gaining an international perspective on constitutional matters. ${ }^{164}$ Constitutional examples from closer to home could prove illuninating as well. Interpretation of the Federal Constitution has had a profound effect on state judges' interpretations of their states' constitutions. ${ }^{165}$ Similarly, greater acquaintance with state charters could offer federal courts an intersystemic benefit.

\section{Federal Voice in a Continuing Constitutional Dialogue}

Authoritative adjudication provides a definitive resolution to a question, and some questions may indeed demand such resolution. Siler, ${ }^{166}$ however, provides but one example of a strong legal impulse to avoid adjudication of constitutional claims. Recent scholarship continues to support the importance of judicial silence, emphasizing the significance of promoting democratic debate about vital issues. Particularly in a diverse, pluralistic society, courts can promote deliberative dialogue by avoiding constitutional decisions that might terminate public debate. ${ }^{167} \mathrm{~A}$ federal court's adjudication of a state constitutional question constitutes a kind of double avoidance, as debate may continue on both state and federal constitutional questions.

Because the Federal Constitution is both supreme and difficult to amend, adjudicating a federal constitutional issue constrains the

164. See, e.g., Printz v. United States, 521 U.S. 898, 977 (1997) (Breyer, J., dissenting) (discussing European models of federalism).

165. See Tarr, supra note 5, at 1110-11. Indeed, mauy would argue that states have been influenced too much by the federal model. For criticisms of states' overdependence on fedcral doctrine, see Shirley S. Abrahamson, Criminal Law and State Constitutions: The Emergence of State Constitutional Law, 63 TEx. L. REv. 1141 (1985); Robert Utter, State Constitutional Law, the United States Supreme Court, and Democratic Accountability: Is There a Crocodile in the Bathtub?, 64 WASH. L. REv. 19 (1989); Robert F. Williams, In the Supreme Court's Shadow: Legitimacy of State Court Rejection of Supreme Court Reasoning and Result, 35 S.C. L. REv. 353 (1984); see also Developments in the Law-The Interpretation of State Constitutional Rights, 95 HARv. L. Rev. 1324 (1982).

166. Siler v. Louisville \& Nashville R.R. Co., 213 U.S. 175 (1909).

167. See Cass Sunstein, One Case at a Time 4, 26-32 (1999) (discussing how avoiding constitutional decision can promote deliberative democracy); James A. Gardner, The Ambiguity of Legal Dreams: A Communitarian Defense of Judicial Restraint, 71 N.C. L. REv. 805, 836-47 (1993) (arguing that by preserving legal ambiguity, avoidance doctrine helps to preserve diverse society); Cass Sunstein, The Supreme Court 1995 Term-Foreword: Leaving Things Undecided, 110 Harv. L. Rev. 4, 19, 36-42 (1996). 
interpretive debate. Avoiding the federal constitutional challenge, by contrast, allows greater freedom for states and for other branches of the federal government to reach their own constitutional conclusions. In addition, delaying the final resolution of the issue may allow for further democratic developments that will add important perspectives to the debate. Avoiding a definitive resolution of federal constitutional issues may thus reduce the risk of judicial error in an area in which the costs of mistake may be quite high. ${ }^{163}$

Relying on state law assures that debate can continue not only on the federal constitutional questions, but on the state constitutional issues as well. Because the federal court cannot authoritatively construe state law, arguments about the meaning of the law outlast the court's decision. Authority may be desirable, but so is debate. When a federal court avoids a federal constitutional decision by deciding a state-law claim, the debates may continue not only about the federal claim, which the court left undecided, but also about the state-law claim, which the court could not authoritatively resolve.

Channeling the claims into state court through such means as abstention and certification elicits definitive rulings from state courts on the state constitutional issues. From the perspective of the state courts, then, abstention and certification are "anti-avoidance" techniques. These practices require state courts to address the state constitutional claims. ${ }^{169}$ In general, the reasons for the avoidance doctrine are weaker in the state constitutional context. Because state constitutions are more easily amended than the Federal Constitution, ${ }^{170}$ state constitutional decisions do not impose equally inflexible rules on society. As the decisions govern only one state, the federal concern for imposing a umiform solution on all states does not arise. Nevertheless, state judges do cite the avoidance doctrine with regard to state constitutional issues, ${ }^{171}$ and avoiding authoritative state constitutional construction allows public debate to continue.

In sum, while the principle of avoiding constitutional rulings may reflect concern about judicial activism and the countermajoritarian implications of judicial review, the version of the avoidance principle advanced

168. See SUNSTEIN, ONE CASE AT A TIME, supra note 167, at 4, 46-54 (discussing avoidance of decisions as means of reducing error costs); Kloppenberg, supra note 10, at 1035-66; Sunstein, The Supreme Court 1985 Term, supra note 167, at 19-20 (discussing benefits of avoiding decisions).

169. State legislatures, of course, invite authoritative resolution when they enact certification statutes.

170. See 31 Council of STATE Governments, supra note 123, at 5-7 (listing constitutional amendment procedures).

171. See, e.g., Johnson v. Bradley, 841 P.2d 990, 1005-06 (Cal. 1992) (Kennard, J., concurring); State v. Killen, 454 A.2d 737, 752 (Del. 1982); Powell v. State, 510 S.E.2d 18 (Ga. 1998); Roosevelt Raceway, Inc. v. Monaghan, 174 N.E.2d 71, 74 (N.Y. 1961); Citizens Comm. to Recall Rizzo v. Board of Elections, 367 A.2d 232, 254 (Pa. 1976) (Eagen, J., concurring); Schultz v. City of Philadelphia, 122 A.2d 279, 284 (Pa. 1956) (Jones, J., dissenting). 
here draws strength from somewhat different sources. Avoidance did receive much support from scholars who sought to limit the occasion for federal constitutional pronouncements so as to avoid undue intrusion into state policies. In Pullman, ${ }^{172}$ Justice Frankfurter championed abstention on such avoidance grounds. To help justify judicial review, the first edition of the Hart and Wechsler casebook highlighted justiciability doctrines that would prevent federal courts from reaching the merits of constitutional cases. ${ }^{173}$ Similarly, Alexander Bickel urged the United States Supreme Court to employ a variety of prudential devices to avoid constitutional adjudications, seeking to prevent the federal courts from unnecessarily taking sides on contentious public issues. Bickel emphasized the value of remaining silent rather than either striking down or validating an existing practice. ${ }^{174}$ This vision of the role of the judiciary has come under attack, ${ }^{175}$ and recent court rulings suggest that it enjoys soniewhat dininished doctrinal support. ${ }^{176}$

A different vision of adjudication, however, underlies the preference explored here for federal adjudication of state constitutional questions. On this view, the problen is not too much constitutional discussion but too little. Avoiding authoritative constitutional decisions allows courts, as well as legislators and citizens, to continue to debate important constitutional values. ${ }^{177}$ Judicial opinions on constitutional issues play a valuable role in shaping public discourse, but authoritative decisions may end the opportunity for discussion. In this sense, Robert Cover has noted that courts serve a "jurispathic" role. ${ }^{178}$ Diverse communities create a rich variety of law, but courts destroy the possibility of alternative legal meanings by fixing on one version as definitive. Significantly, however, federal adjudication of state constitutional issues advances debate about important constitutional values, but cannot end it. Such adjudication can thus promote a variety of legal

172. Railroad Comm'n of Texas v. Pullman, 312 U.S. 496 (1941).

173. See Akhil Reed Amar, Law Story, 102 Harv. L. Rev. 688, 701-02 (1989).

174. See AleXANDER M. Bickel, The LEAST DANGerous BRANCh 69-72 (2d ed. 1986).

175. See Amar, supra note 173, at 702-10.

176. Pullman abstention itself fell into relative desuetude after Justice Felix Frankfurtcr's retirement in 1962. See FALLON ET AL., supra note 38, at 1237. A willingness to eschew the avoidance principle in favor of other interests is apparent in such decisions as Pennhurst, 465 U.S. 89 (1984), which prohibits reliance on pendent state grounds, and Michigan v. Long, 463 U.S. 1032 (1983), which creates a presumption that a state court decision rests on federal constitutional grounds. The Court also has shown some flexibility in the areas of ripeness, see FALLON ET AL., supra note 38 , at 1285 \& n.3, and mootness, see United States Parole Comm'n v. Geraghty, 445 U.S. 388 (1980) (holding that expiration of named plaintiff's claim does not moot class action).

177. Cf. Neal Kumar Katyal, Judges as Advicegivers, 50 STAN. L. REv. 1709 (1998) (discussing valuable "advicegiving" role of judicial opinions).

178. Robert M. Cover, The Supreme Court 1982 Term Foreword: Nomos and Narrative, 97 HARv. L. REv. 4, 40-44 (1983) (discussing "jurispathic" role of courts). 
perspectives, avoiding a "jurispathic" judicial role. ${ }^{179}$ To the extent that opinions on constitutional issues should evoke celebration, not fear, this kind of avoidance allows the celebration to continue. Thus, it is true that by addressing the state constitutional claim, courts do avoid the federal constitutional ruling, but this avoidance of authoritative adjudication actually promotes constitutional discourse by courts and others. ${ }^{180}$

Constitutional law does not simply provide a locus for dialogue about a polity's fundamental norms; it also prescribes particular rules for governing behavior. If conflicting imterpretations develop that impose inconsistent obligations, some defimitive resolution is required. An authoritative power also may intercede if an interpreter strays too far from the borders of what the authority understands to be reasonable. Within these bounds, interpretive diversity can be constructive of meaning without becoming destructive of order.

\section{Weakness in State Constitutionalism}

The argument so far has focused on the theoretical relationship between structure and interpretation. At the most general level, state and federal court systems differ in important institutional respects, and these differences imight produce a useful dialogue between the two. Further, given the value attributed to judicial independence in other contexts, the contributions of the more politically insulated federal judiciary might prove particularly important. These views do not necessarily depend on any predisposition to favor the side of the government or the individual in the constitutional dispute. ${ }^{181}$ Concern for protecting the rights claimant, though, does provide additional support for a robust federal role in state constitutional adjudication.

Dissatisfaction with the actual practice of state courts in interpreting state constitutions bolsters these theoretical claims. A fairly widespread perception exists that state constitutionalism has failed to reach its true potential for providing alternative sources of protection for individual rights. Though state constitutions have been construed to provide some important protections to individuals, the charters generally have not staked out important new safeguards for minority interests. ${ }^{182}$ This unfavorable

179. See Rubinson, supra note 1, at 15-16 (discussing polyphony as avoidance of the "jurispathic" function of law).

180. Cf. Sanford Levinson, Constitutional Faith 27-30 (1988) (describing "Protestant" approach to constitutional interpretation).

181. Cf. Michael Wells, Naked Politics, Federal Courts Law, and the Canon of Acceptable Arguments, 47 EMORY L.J. 89 (1998) (describing and criticizing exclusion of arguments based on "naked politics" from canon of acceptable federal courts arguments).

182. See Paul W. Kahn, State Constitutionalism and the Problem of Fairness, 30 VAL. U. L. REv. 459, 465 (1996); see also Daniel B. Rodriguez, State Constitutional Theory and Its Prospects, 28 N.M. L. REV. 271, 271 (1998) (citing "disappointing" results of the "turn toward state constitutional discourse"). State constitutions generally have not been interpreted to provide more rights than the 
evaluation of state constitutional litigation may reflect in part the complaints of disappointed liberals, who sought refuge in state constitutions when the achievements of the Warren Court appeared threatened by the Burger and Rehnquist Courts. ${ }^{183}$ The criticism of state constitutionalism, however, has focused not only on the results of the decisions, but also on flaws in the interpretive methods commonly adopted by state courts. ${ }^{184}$

To the extent that state courts exhibit these weaknesses, either in result or in manner of interpretation, federal contributions to state constitutional discourse would be especially important. Federal adjudication of state constitutional claims could perform a kind of truth-in-advertising function, requiring states to confront their constitutions and to amend them if necessary, rather than avoiding the constitutional commands through

Federal Constitution. See, e.g., Barry Latzer, State Constitutions and Criminal Justice 158 (1991) (finding little state court deviation from federal doctrine); Craig F. Emmert \& Carol Ann Traut, State Supreme Courts, State Constitutions, and Judicial Policymaking, 16 Just. SYs. J. 37 (1992) (survey finding extensive state court reliance on federal law); Susan P. Fino, Judicial Federalism and Equality Guarantees in State Supreme Courts, 17 Publius 51 (1987) (same); James A. Gardner, The Failed Discourse of State Constitutionalism, 90 Mich. L. Rev. 761, 780-84 (1992) (same); Barry Latzer, Into the '90s: More Evidence that the Revolution Has a Conservative Underbelly, 4 EMERGING Issues St. Const. L. 18 (1991) (same); Barry Latzer, The Hidden Conservatism of the State Court "Revolution", 74 JudiCATURE 190 (1991) (same); Solimine \& Walker, Federalism, Liberty, and State Constitutional Law, supra note 138, at 1467 ("Despite the considerable hoopla afforded a few decisions from a few states, the vast majority of state courts follow federal law when construing the libertyprotecting provisions of their own constitutions ...."); Tarr, supra note 5, at 1114-17 (summarizing research finding limited state court reliance on state constitutions); G. Alan Tarr, The Past and Future of the New Judicial Federalism, 24 Publius 63, $74-77$ (1994) (same). In the area of school finance reform, Professor Douglas Reed has found that state constitutional litigation may have significant effects on the distribution of educational resources, but he too finds a lack of activism by state courts. See Douglas R. Reed, Twenty-Five Years After Rodriguez School Finance Litigation and the Impact of the New Judicial Federalism, 32 L. \& Soc'Y REv. 175, 213 (1998); see also Note, Unfulfilled Promises: School Finance Remedies and State Courts, 104 HARv. L. REv. 1072, 1082-83 (1991) (noting reluctance of judiciary to enforce state constitutional rigbts to school funding equity). Commentators have noted a similar judicial reluctance to enforce state constitutional rights to welfare. See Helen Hershkoff, Positive Rights and State Constitutions: The Limits of Federal Rationality Review, 112 HARV. L. REv. 1131, 1136 \& n.18 (1999).

183. See, e.g., Ronald K.L. Collins, Reliance on State Constitutions-Away from a Reactionary Approach, 9 HASTINGS CoNST. L.Q. 1 (1981) (noting critically result-oriented, instrumentalist approach to state constitutions); Ken Gormley, Ten Adventures in State Constitutional Law, 1 EMERGING IssuEs ST. ConST. L. 29, 31 (1988) (describing first surge of state constitutional decisions as "hammer-to-theknee reflex to conservative opinions" of United States Supreme Court); Kahn, supra note 182, at 464 ("State constitutionalism represented a kind of forum shopping for liberals."); Paul W. Kahn, Two Communities: Professional and Political, 24 RuTgers L.J. 957, 968 (1993) (describing state constitutionalism as driven in part by the desire to create a "counterforce to the increasingly conservative federal courts"). For commentaries criticizing the liberal instrumentalist view of state constitutionalism, see Earl M. Maltz, False Prophet-Justice Brennan and the Theory of State Constifutional Law, 15 Hastings Const. L.Q. 429 (1988); Earl M. Maltz, The Dark Side of Siate Court Activism, 63 TEx. L. REv. 995 (1985); Earl M. Maltz, The Political Dynamic of the "New Judicial Federalism", 2EMERging IssuEs St. CONST. L. 233 (1989); Steven J. Twist \& Mark Edward Hessinger, New Judicial Federalism: Where Law Ends and Tyranny Begins, 3 EMERGING IssuEs ST. CoNST. L. 173 (1990).

184. See Hershkoff, supra note 182, at 1153-69 (criticizing theoretical underpinning of states' use of federal rationality review standard); Schapiro, supra note 162, at 404-14. 
judicial underenforcement. By drawing out the full implications of state constitutional protections, the federal courts could ensure that state courts do not duck important constitutional issues. One of the distinguishing features of American constitutionalism is that our constitutions are not merely hortatory, but rather are legally enforceable. ${ }^{185}$ Federal courts could help guarantee that state constitutional provisions do not languish unenforced. ${ }^{186}$ Federal courts could not reject state constitutional precedent, but they could provide a valuable alternative perspective, rooted in a different institutional context. In the articulation of state constitutional law, the state courts would remain the authoritative, but not the only, voice. ${ }^{187}$

The advantages of federal court interpretation of state constitutions do not depend on a rejection of Erie or an embrace of natural law. Historically, state and federal courts did rely on natural law principles in cases involving individual rights. ${ }^{188}$ That natural law background endured even when federal courts professed to be bound by state courts' interpretations of state constitutions. ${ }^{189}$ Today, some scholars continue to view constitutional interpretation as a practice not tied to a specific text. Professor Paul Kahn, for example, views state constitutional interpretation as a project that should look to a common text of American constitutionalism, rather than to the language or traditions of a particular state's constitution..$^{190} \mathrm{I}$ have criticized that view elsewhere, ${ }^{191}$ and I do not embrace it here. The benefits of intersystem dialogue do not depend on viewing constitutional interpretation as an inquiry into natural law or into general common law. ${ }^{192}$ Federal courts can contribute to state constitutional interpretation without

185. See William W. Van Alstyne, The Idea of the Constitution as Hard Law, 37 J Legal Educ. 174, 180 (1987).

186. For an example of federal courts' ensuring the enforcement of state constitutional provisions, see infra Part IV.F (discussing litigation over crosses on public property).

187. See Paul W. Kahn, Interpretation and Authority in State Constitutionalism, 106 HARv. L. REV. 1147, at 1163-67 (1993) (discussing distinction between "interpretive task" and "authoritative voice"); see also Cover \& Aleinikoff, supra note 158, at 1048-51 (discussing different institutional perspectives of state and federal courts and value of dialogue between them); $c f$. Bator, supra note 4 , at 634-35 (contrasting hierarchical view of law making as primarily requiring obedience to higher authority with "richer, and more coherent" account of law making as a "cooperative enterprise" involving mutual and reciprocal obligations of reasoned elaboration).

188. See Suzanna Sherry, Natural Law in the States, 61 U. CiN. L. REv. 171 (1992); Suzanna Sherry, State Constitutional Law: Doing the Right Thing, 25 Rutgers L. J. 935 (1994); Suzanna Sherry, The Early Virginia Tradition of Extratextual Interpretation, in TowaRD A UsEABLE Past: Liberty Under State Constitutions 158-59 (Paul Finkelman \& Stephen E. Gottlieb eds., 1991); Suzanna Sherry, The Founders' Unwritten Constitution, 54 U. CHI. L. REV. 1127 (1987).

189. See Gelpcke v. City of Dubuque, 68 U.S. (1 Wall.) 175, 206-07 (1863) ("We shall never immolate truth, justice, and the law, because a State tribunal has erected the altar and decreed the sacrifice.").

190. See Kahn, supra note 187, at 1159-62; see also id. at 1161 ("There is not one equality in Connecticut and another in Texas, or even Utah.").

191. See Schapiro, supra note 162, at 433-34.

192. See Hans A. Linde, Are State Constitutions Common Law?, 34 ARIz. L. Rev. 215 (1992) (criticizing view of constitutions as common law). 
overruling Erie. ${ }^{193}$ An interpreter with a different institutional perspective, who has explored concepts such as liberty, equality, and due process in other settings, may have valuable insights into the interpretation of the particular concept of liberty, equality, or due process embodied in a specific state constitution.

\section{E. Counterarguments}

This Article has explored some of the benefits of federal interpretation of state constitutions. State court interpretation of state constitutions has many advantages as well. This Section considers whether federal adjudication of state constitutional claims would interfere with some of the key features of state constitutionalism.

\section{Political Accountability and Legitimacy}

Contrary to the notion that constitutionalism requires insulation, some commentators assert that state constitutionalism benefits from greater sensitivity to democratic forces. These commentators generally emphasize two features that distinguish state constitutional adjudication from the more politically isolated federal model: the enhanced electoral accountability of state judges and the relative ease of state constitutional amendment. From this perspective, federal adjudication might undermine desirable majoritarian features of state constitutionalism.

\section{a. In Defense of Democracy}

Some have argued that the greater political accountability of state judges might help confer legitimacy on their adjudication of state constitutional claims. ${ }^{194}$ This concept of legitimacy relates both to the general reception of a ruling and to the internal adjudicative process. Because of their place in the political system, the decisions of state judges might

193. The analysis in this Article thus does not depend on a particular position in the debate over the relationship between Erie and positivism. See, e.g., Bradford R. Clark, Ascertaining the Laws of the Several States: Positivism and Judicial Federalism After Erie, 145 U. PA. L. REv. 1459, 1479-84 (1997) (discussing Erie's connection with positivism); Jack Goldsmith \& Stcven Walt, Erie and the Irrelevance of Legal Positivism, 84 VA. L. REv. 673 (1998) (diseussing critically arguments connecting Erie with positivism); George Rutherglen, Reconstructing Erie: A Comment on the Perils of Legal Positivism, 10 Const. Comment. 285 (1993) (same); see also Richard D. Frcer, Some Thoughts on the State of Erie after Gasperini, 76 TEx. L. REv. 1637 (1998) (discussing eurrent state of Erie doctrine); Richard D. Freer, Erie's Mid-Life Crisis, 63 TUL. L. REv. 1087 (1989) (analyzing continuing problems with application of Erie doctrine).

194. See Daan Braveman, Children, Poverty and State Constitutions, 38 Emory L.J. 577, 609-10 (1989); Judith S. Kayc, Contributions of State Constitutional Law to the Third Century of American Federalism, 13 VT. L. Rev. 49, 56 (1988); Neuborne, supra note 24, at 899-900; Lawrence Schlam, State Constitutional Amending, Independent Interpretation, and Political Culture: A Case Study in Constitutional Stagnation, 43 DePAul L. Rev. 269, 288-89 (1994); Utter, supra note 165, at 35; Mark Jacob, Note, Lawyers Beware: Davenport v. Garcia Could Signal a Change in Constitutional Analysis, 13 Rev. LiTig. 281, 292 (1994). 
receive greater public acceptance. ${ }^{195}$ Rather than decrying the tyranny of an unelected judiciary, citizens may perceive court rulings to be firmly situated in the state political system. Judicial decisions would have the same claim to democratic legitimacy as any other product of the popularly elected state government. In addition, their greater accountability imight render state judges more willing to read state constitutional guarantees expansively. ${ }^{196}$

The descriptive accuracy of this accountability theory is not readily subject to verification. ${ }^{197}$ It is difficult to document how perceived democratic legitimacy influences public reception of judicial decisions. The argument that greater electoral accountability emboldens state court judges seems even more questionable, even though two of the chief proponents of the accountability thesis are themselves state high court judges. ${ }^{198}$ The comparative studies of state courts that correlate judicial independence with protection of minority rights raise serious questions about this aspect of the accountability theory. ${ }^{199}$ The studies instead support the argument, faimiliar from the federal-state parity debates, that imsulation, rather than accountability, provides an environment conducive to a robust interpretation of constitutional rights. ${ }^{200}$ In a survey of state judges conducted by the American Judicature Society, for example, $15.4 \%$ stated that retention elections made them avoid controversial cases and rulings, while $7.0 \%$ reported that such elections made them more secure to make controversial

195. See Nathan S. Heffernan, Judicial Responsibility, Judicial Independence and the Election of Judges, 80 MARQ. L. REv. 1031,1046 (1997).

196. See Braveman, supra note 194, at 610; Neuborne, supra note 24, at 900; Schlam, supra note 194, at 293-94; Robert S. Thompson, Judicial Retention Elections and Judicial Method: A Retrospective on the California Retention Election of 1986, 61 S. CAL. L. REV. 2007, 2055 (1988) ("Subjecting state appellate judges to electoral accountability conceivably justifies these judges in erring more freely on the side of overprotection [of minority rights]."); see also Heffernan, supra note 195, at 1047 (pointing out that elected state judiciaries resisted enforcement of Fugitive Slave Law to a greater degree than appointed Justices of the United States Supreme Court). On the other hand, Hans Linde, one of the leading scholars of state constitutions and a Senior Judge on the Oregon Supreme Court, has criticized forcefully the notion that the method of selection should influence a judge's decisions: "Judges as well as commentators should abandon the facile notion that legal interpretation by elected judges has either greater legitimacy or greater latitude than by appointed judges. The distinction undercuts the courts' claim of professional fidelity to law. ..." Hans A. Linde, The Judge as Political Candidate, 40 CLEV. ST. L. REv. 1, 16 (1992); see also Enoch, supra note 20, at 731-34 (criticizing normative foundations of accountability theory).

197. See Ludwig, supra note 128, at 35 ("In my experience, the election of judges as an expression of popular sovereignty is a fiction and, at times, an ugly one."); Wiener, supra note 126, at 205-06 (questioning whether elections lead to accountability);

198. See Kaye, supra note 194; Utter, supra note 165.

199. See supra note 136 (citing sources).

200. See Kahn, supra note 182, at 465,471 (noting "structural weakness confronting state constitutionalism" resulting from state courts being "closer to the people" than are federal courts and criticizing the theory that accountability emboldens state constitutional interpretation); see also Robert F. Nagel, Political Pressure and Judging in Constitutional Cases, 61 U. Colo. L. REv. 685, 685-86 (1990) (noting connection between insulation and judicial contribution to public decision making). 
rulings. ${ }^{201}$ Indeed, even the commentators who suggest that accountability might enhance judicial protection of constitutional rights acknowledge the dangers of majoritarian pressures. ${ }^{202}$

\section{b. The Benefits of Soft Law}

Not only are state judges generally more subject to electoral pressure, their constitutional decisions also are much easier to reverse than federal constitutional decisions. One of the distinguishing features of the Federal Constitution is its relative impermeability. ${ }^{203}$ State constitutions, by contrast, are much easier to amend. ${ }^{204}$ In comparison to the twenty-seven amendments to the United States Constitution, state constitutions have been amended more than five thousand times. ${ }^{205}$ This greater ability to revise constitutional interpretations may lessen the legitimacy concerns that arise from the countermajoritarian nature of federal judicial review. As in the case of the electoral accountability of judges, commentators argue that state judges feel less constrained in their constitutional decision making because of the opportunity for democratic revision. ${ }^{206}$

The general ease of amendment of state constitutions, however, does not detract from a federal role in construing state constitutions. Federal court interpretation of state constitutions also would be open to popular revision. An unpopular construction of the state constitution could be reversed by constitutional amendment whether the interpretation flowed from a state or federal judge. The main difference would be the lack of state electoral checks on the judges themselves. For the reasons just discussed, it is not at all clear that the lack of electoral accountability would hamper federal court interpretation.

201. See Larry T. Aspin \& William K. Hall, Retention Elections and Judicial Behavior, 77 Judicature 306, 312-13 (1994). A more ambiguous response that retention elections made judges "more sensitive to public opinion" was offered by $27.6 \%$ of the respondents. Id. Overall, $60.5 \%$ of the judges reported that retention elections altered the behavior of judges on the bench. See id. at 312; see also Hall, Electoral Politics, supra note 136, at $442-43$ (presenting study showing that judicial elections incline judges to adopt positions held by popular majorities).

202. See Braveman, supra note 194, at 610 ("One might reasonably conclude that the political accountability of state judges does not enhance, but instead reduces, the likelihood that state courts will pursue an independent approach that is more protective of poor children."); Neuborne, supra notc 24, at 900 (citing "darker side of that democratic imprimatur"); Utter, supra note 165, at 43 ("Democratic accountability of state appellate court judges does have a revcrse side.").

203. See Van Alstyne, supra note 185, at 179, 183.

204. See 31 Council of State Governments, supra note 123, at 5-7 (listing constitutional amendment procedures).

205. See Utter, supra note 165 , at 35 .

206. See Braveman, supra note 194, at 611 ("[S]tate judges may have greater frcedom to act precisely because they know their determinations are redressable by the people."); Neuborne, supra note 24, at 900. But cf. Kahn, supra note 182, at 471 (noting structural weakness of easily amended constitutions); Van Alstyne, supra note 203, at 183 (discussing advantages of constitutions that are not easily amended). 
A related argument, with parallels in debates about diversity jurisdiction, is that as outsiders, federal courts would feel more constrained in creatively expounding state constitutional law. Federal judges might be hampered in particular by the absence of a tradition of judicially fashioning common law rules. ${ }^{207}$ This hypothesis, too, is difficult to verify, and the previous discussion of "cross-pollination" in the diversity context suggests that federal courts do have contributions to make to state jurisprudence. Unlike a state supreine court, the federal court could not explicitly overrule a binding state constitutional precedent, but few cases present such direct confrontations with prior decisions. Lower court rulings play an important role in shaping the development of the law. ${ }^{208}$ Federal courts have as nuch power as lower state courts to unove state law in new directions. ${ }^{209}$

\section{The Accidental Character of Supplemental Jurisdiction}

Whatever the potential benefits of federal court adjudication of state constitutional claims, the apparent lack of a statutory or constitutional mandate poses serious questions of legitimacy. The availability of a federal forum for federal constitutional claims reflects a statutory ${ }^{210}$ and constitutional $^{211}$ judgment of the importance of federal courts to the vimdication of federal rights. The authority of a federal court to adjudicate state-law claims between diverse citizens rests on similarly strong foundations. ${ }^{212}$ Supplemental jurisdiction, by contrast, stems from more pedestrian concerns for efficient case packaging. ${ }^{213}$ The federal adjudication of the state claim seems at best a tolerated, if unwanted, happenstance.

I do not seek to avoid or to rewrite that legislative and constitutional history. Whatever the intentions of the framers or drafters, though, the potential benefits of federal adjudication of state constitutional claims are

207. See Braveman, supra note 194 , at 611 ; Neuborne, supra note 24 , at $896-97$.

208. For a discussion of the proper role of lower courts in a system governed by the principle of stare decisis, see Evan H. Caminker, Precedent and Prediction: The Forward-Looking Aspects of Inferior Court Decisionmaking, 73 TEx. L. Rev. 1 (1994).

209. See Richard D. Freer \& Wendy Collins Perdue, Civil Procedure Cases, Materials, AND QUEsTIONS 350 ( $2 \mathrm{~d}$ ed. 1997) ("It is hard to generalize whether a federal court will be more or less conservative than its state counterparts in declaring state law to have changed."). When they construe state law, federal courts thus do more than "play the role of the ventriloquist's dummy." Richardson v. Commissioner, 126 F.2d 562, 567 (2d Cir. 1942). In addressing state-law questions, federal courts rely on all available guides to judicial decision, just as would a court of that state. See Wright, supra note 40 , at 395.

210. See 28 U.S.C. $\$ \$ 1331,1343$ (1994).

211. See U.S. CoNST. art. III; see also Akhil Reed Amar, Of Sovereignty and Federalism, 97 YALE L.J. 1425, 1483 (1987) (discussing importance of availability of federal forum for vindication of federal right).

212. See U.S. CONST. art. III; 28 U.S.C. \$ 1332 (1994).

213. See FRIEDENTHAL ET AL., supra note 53, $\$ 2.12$, at 69 ; see also supra note 53 (citing sources). 
substantial, even if unintended. ${ }^{214}$ In an area that relies explicitly on a balancing of policy judgments, these benefits deserve weight. Moreover, the existence of federal jurisdiction over dual constitutional claims at least coincides with the existence of significant federal interests. Dual constitutional claims necessarily involve an alleged violation of federally protected rights. The state constitutional issue thus implicates concerns of national scope. The advantages of cross-pollination and of politically insulated tribunals are especially significant in such realms. Federal adjudication of the state half of dual constitutional claims is a well-tailored form of federal intervention into the state-law process.

\section{Undermining State Constitutionalism}

The potential for undermining state constitutionalism poses the most powerful objection to federal adjudication of state constitutional claims. A robust federal role could induce states to grant fewer rights to their citizens, and federal court interpretation might dilute the efforts of state courts to interpret their constitutions independently of the federal charter.

\section{a. The Perverse Incentives of Federal Enforcement}

In Pennhurst, ${ }^{215}$ the United States Supreme Court held that federal adjudication of state-law claims against the state itself violated federalism principles embodied in the Eleventh Amendment. ${ }^{216}$ The Court, however, did little to explicate the nature of the values at stake. Professor Ann Althouse has provided a more thorough elaboration of the argument supporting the holding of Pennhurst. Her work asserts that the attempt by federal courts to enforce state law against states would subvert efforts by states to develop their own systems for protecting individual rights. ${ }^{217}$

Professor Althouse argues that states might wish to create safeguards for individual rights, but might want these protections to be enforceable only in state court. Judicial interpretation helps to define the substance of a right, and the state imight prefer that an organ of the state give definition to the right. ${ }^{218}$ Further, litigation over individual rights can involve complex and protracted remedial issues. ${ }^{219}$ The state might not want to cede ongoing supervision of a state agency to a federal tribunal. For all of these reasons, Professor Althouse suggests that federal enforcement might create incentives for states to avoid new protections and to define existing safeguards

214. Some of the presumed benefits of diversity jurisdiction also may reflect happenstance, rather than conscious design. See Redish, supra note 121, at 1773 (questioning whether intersystemic interaction was "incidental by-product of a system designed to achieve other goals").

215. Pennhurst State Sch. \& Hosp. v. Halderman, 465 U.S. 89 (1984).

216. See id. at 107.

217. See Althouse, supra note 17, at 1521-24.

218. See id:; Althouse, supra note 133, at 966.

219. See Althouse, supra note 17, at 1523. 
narrowly. ${ }^{220}$ Federal adjudication would thus have the perverse effect of contracting the individual liberties granted by state law.

Professor Althouse's arguinents focus primarily on statutory, rather than constitutional provisions. ${ }^{221}$ Her claims apply with dimimshed force in the state constitutional context. The legislative adoption of protections for individual rights suggests that these guarantees enjoy current democratic support because the majority, acting through its representatives, has chosen to safeguard certain liberties. In this setting, the fear that majoritarian forces would threaten to overwhelm these same protections has less power. By the same token, if the legislature did not want federal enforcement of these rights because of potential or actual imstances of overreaching, revocation of the protections could be swiftly and relatively easily accoinplished. With regard to statutory protections, political insulation appears somewhat less important, and great opportunity exists for swift backlash against federal intrusion.

State constitutional guarantees, by contrast, are more likely to reflect a desire to safeguard certain values against majoritarian pressures. Constitutional provisions may present greater tension with current sensibilities than do statutes, which tend to be of inore recent vintage. Judicial insulation therefore may be more important in the state constitutional, as opposed to statutory, context. Reflexive retaliation against perceived federal ineddling also presents less of a concern in the constitutional setting. Because they are much easier to amend, state constitutions are more sensitive to democratic forces than is the Federal Constitution. Nevertheless, state constitutions provide greater protection from the shifting whims of current majorities than do state statutes. The slightly enhanced obstacles to revision would require greater deliberation and participation before a federal interpretation could be overruled. Moreover, given the holding of Pennhurst, the defendants im federal court will be localities or other subdivisions, rather than the state itself. Federal enforcement of state law agamst such an entity will have a more limited geographic scope than federal adjudication of claims directly against the state. These narrower enforcement actions will be less likely to provoke state-wide efforts to repeal the state constitutional provision at issue. ${ }^{222}$

More generally, federal adjudication of state constitutional claims need not be seen as a perversion of federalism. Indeed, to the extent one understands federalism fundamentally as a protection of individual liberty, rather than as a protection of state dignity, federal enforcement of state

220. See id. at 1521-23.

221. See id. at 1521 (describing, with reference to Pennsylvania law at issue in Pennhurst, possible broader federal interpretation of state law as a "penalty" that might discourage state legislation protecting individual liberties).

222. See also Lee \& Wilkens, supra note 4, at 339-40 (suggesting that federal adjudication of state law is unlikely to cause "friction" with state). 
constitutional rights advances, rather than undermines, federalist principles. Akhil Amar has strongly urged this "neo-federalist" perspective on the role of states. ${ }^{223}$ Professor Amar has focused on the important role that states might undertake in safeguarding federal constitutional rights against federal intrusion. For example, he advocates the adoption of state "converse-1983" laws, providing a state-created cause of action for a violation of federal rights by the federal government. ${ }^{224}$ Such an action, he has maintained, would violate no legitimate interests of federal sovereignty: How could the federal government object to this supplemental avenue for the vindication of federal rights?25 Similarly, supplemental jurisdiction allows the federal government to play a role in safeguarding state constitutional rights against state intrusion. Such federal adjudication of state constitutional issues might well advance the neo-federalist principle of safeguarding individual rights against governmental impairment. To be sure, Professor Amar inanifests soine skepticisin toward state constitutions as expressions of federalism. After all, he points out, if we did not have states in the first place, we would not need state constitutions to protect us against state oppression. ${ }^{226}$ To build on the thrust of Professor Amar's argument, though, if states are necessary to guard the people against federal tyranny, state constitutions provide additional checks on the guards. Moreover, the jurisdictional principles advocated herein ensure that no procedural impediments, such as routine abstention, hinder the fundamental constitutional value of affording a federal forum for the vindication of a federal right. ${ }^{227}$

223. See Akhil Reed Amar, A Neo-Federalist View of Article III: Separating the Two Tiers of Federal Jurisdiction, 65 B.U. L. REv. 205 (1985) [hereinafter Amar, Neo-Federalist View]; Amar, supra note 211, at 1492-93; see also New York v. United States, 505 U.S. 144, 181 (1992) ("[T]he Constitution divides authority between federal and state governments for the protection of individuals. State sovereignty is not just an end in itself: 'Rather, federalism secures to citizens the libcrties that derive from the diffusion of sovereign power."' (quoting Coleman v. Thompson, 501 U.S. 722, 759 (1991) (Blackmun, J., dissenting))). But $c f$. id. at 157 ("The benefits of this fedcral structure have been extensively cataloged elsewhere... but they need not concern us here. Our task would be the same even if one could prove that federalism secured no advantages to anyone."). For an incisive discussion of the promise and peril of attributing purposes to federalism, see Michacl C. Dorf, Instrumental and Non-Instrumental Federalism, 28 RUTGERS L.J. 825 (1997).

224. See Akhil Reed Amar, Five Views of Federalism: 'Converse-1983' in Context, 47 VAND. L. REv. 1229 (1994) [hereinafter Amar, Five Views of Federalism]; Amar, supra note 211, at 1512-19; Akhil Reed Amar, Using State Law to Protect Federal Constitutional Rights: Some Questions and Answers About Converse-1983, 64 U. CoLo. L. REv. 159 (1993) [hereinafter Amar, Using State Law].

225. See Amar, Using State Law, supra note 224, at 163.

226. See Amar, Five Views of Federalism, supra note 224, at 1244-45; Amar, Using State Law, supra note 224 , at $177-78$.

227. See Amar, Using State Law, supra note 224, at 164-65. Abstention would burden dual constitutional challenges, potentially leading plaintiffs to file state and federal claims in a state court. As Professor Amar acknowledges, the limitations on the Supreme Court's certiorari docket currcntly mean that state courts as a practical matter have the last word on the federal claims that they adjudicate. See Amar, supra note 12, at 646. 


\section{b. The Danger of Federal Monologue}

Federal courts could provide useful contributions to the development of state constitutions. The value of such federal-state dialogue, however, depends on federal courts' commitments to engage in serious reflection on the meaning of state constitutions. A danger certainly exists that, steeped in federal constitutional tradition, federal judges will view a state constitution as a mirror, simply reflecting back the doctrines developed in construing the Federal Constitution. Federal courts' crowded dockets and their relative inexperience with state constitutional issues enhance the appeal for them of applying the more familiar federal doctrine. Largely free of federal court involvement, some state courts have developed their own constitutional discourses. The states have not always chosen independent paths, and commentators have criticized the tendencies of states to mimic federal forms. ${ }^{228}$ It is not clear, though, whether federal courts would do a better job of developing an independent state constitutional jurisprudence. Indeed, federal courts might further dilute state constitutional doctrine, endowing state constitutional law with an increasingly homogenized, federal cast. Perhaps state constitutions have profited from federal courts' benign neglect. ${ }^{229}$

Time will tell whether federal courts indeed fail to engage in a useful constitutional dialogue and whether such federal decisions divert state doctrine from an independent conrse. The limited experience so far suggests that this fear may be unfounded. The Boston police drug testing case, for example, demonstrates that a state high court may continue to develop its own approach to state constitutional interpretation, even after a federal court construes a state provision to mirror federal doctrine ${ }^{230}$ A state court interested in constructing an independent state constitutional tradition may not be easily dissuaded by a federal court's Johnny-one-note insistence on following federal patterns.

\section{F. Dual Constitutionalism in Practice: California Crosses}

The role of federal courts in interpreting the Califorma Constitution illustrates some of the productive possibilities for a federal contribution to state constitutional law. The California Constitution contains a No Preference Clause, ${ }^{231}$ which the California courts have construed to sweep

228. See supra note 182 (citing sources).

229. I am grateful to Ben Sheffner of the California Law Review for suggesting this argument.

230. Compare Guiney v. Roache, 833 F.2d 1079 (1st Cir. 1987) (refusing to hold that state constitutional provision had meaning different from federal analogue), with Guiney v. Police Comm'r of Boston, 582 N.E.2d 523 (Mass. 1991) (holding that state constitutional provision provided greater privacy rights than federal Fourth Amendment). The Guiney litigation is discussed supra at text accompanying notes $94-97$.

231. CaL. Const. art. I, $\$ 4$ ("Free exercise and enjoyment of religion without discrimination or preference are guaranteed."). 
more broadly than the Federal Establishment Clause in requiring government neutrality toward religion. ${ }^{232}$ Federal courts have applied the No Preference Clause in controversial cases, involving such matters as crosses on public property and on city insignia..$^{233}$ In these instances, federal judges have interpreted the California Constitution to require the unpopular action of removing the crosses. The structural insulation of the federal judges allowed them to make these rulings without fear of political retribution.

A federal district court's decision to enjoin the maintenance of crosses on Mt. Helix and Mt. Soledad in the San Diego area, for example, triggered sharp public reaction, ${ }^{234}$ provoking protest marches and angry letters to newspapers. ${ }^{235}$ The claimed status of the Mt. Soledad cross as a veteran's inemorial engendered particular outrage. ${ }^{236}$ The attorney for the City of San Diego charged that opponents of the cross "shame the memory of those valiant men and women who fought and died to preserve" freedoin of religion, and he chastised the opponents for "ignor[ing] the rights of the majority."237 Not surprisingly, some of the attacks were directed at the federal district judge, Gordon Thompson, Jr. The judge was accused of "judicial tyranny," "238 and one writer asserted that "[t]he judge would have us exchange the 'reactionary' Christian moral behavior, respect for others and tolerance, with politically correct moral relativism and the primacy of the judiciary, with judges and lawyers as the new high priests."239

In sum, the cross litigation presented exactly the kind of situation in which political insulation could be expected to assist a judge in protecting minority rights. Indeed, one commentator insisted that the controversy demonstrated the importance of protecting judges froin political reprisal:

232. See Hewitt v. Joyner, 940 F.2d 1561, 1566-67 (9th Cir. 1991) (citing Sands v. Morongo Unified Sch. Dist., 809 P.2d 809 (Cal. 1991) (Kennard, J.); Okrand v. City of Los Angeles, 254 Cal. Rptr. 913, 916 (Cal. Ct. App. 1989)).

233. See Ellis v. City of La Mesa, 990 F.2d 1518 (9th Cir. 1993) (consolidated appeal of three cross cases).

234. See Murphy v. Bilbray, 782 F. Supp. 1420 (S.D. Cal. 1991), aff'd sub nom. Ellis v. City of La Mesa, 990 F.2d 1518 (9th Cir. 1993); Kittle, The Cross Controversy, SAN Diego Union-TribunE, Dec. 7, 1991, at B-12.

235. See David Harpster, Hundreds Brave Cold to Pray at Mount Helix Cross; Decision on Site Remains, San Diego Union-Tribune, Dec. 22, 1992, at B-2; Removal of Crosses: Was Decision Proper?, SAN Diego Union-Tribune, Dec. 12, 1991, at B-22 (letters to the editor); Bob Rowland, Candles Light Way for Protesters on March to Save Cross Atop Helix, San Diego Union-Tribune, Dec. 24, 1991, at B-1; Lionel Van Deerlin, Law Protects Judge From Being Crucified, SAN Diego Union-Tribune, Dec. 10, 1991, at B-9.

236. The district court found scant evidence that the cross served as a war memorial. See Murphy v. Bilbray, 782 F. Supp. 1420, 1438 (S.D. Cal. 1991) ("Faced with this battery of evidence, it is difficult to conclude that the commemorative objective advanced by the City is anything other than pretext.").

237. John Witt, Cross Historically Used to Commemorate Veterans, SAN Diego Union-Tribune, Dec. 13, 1991, at B-15.

238. Harold Roll \& Donna Roll, The Cross Debate, SAN Diego UnIon-TRIBUnE, Dec. 6, 1991, at B-11.

239. Neil Hokanson, Cross Controversy, SAN DiEgo Union-Tribune, Dec. 8, 1991, at B-2. 
[T]he ruckus [Judge Thompson's] ruling has stirred up may provide a timely reminder of why federal judges enjoy lifetime tenure .... If we really believe that majority rule aims to protect the rights of a minority, this judicial freedom from retribution seems essential. Thompson was free to make a finding on crosses-and on the law-without regard to its inevitable unpopularity. ${ }^{240}$

A California state judge, subject to an election or retention ballot, ${ }^{241}$ also might have braved public outcry. Nevertheless, the cross controversy certainly illustrates how federal judges' insulation might allow them to play a particularly valuable role in state constitutional adjudication. ${ }^{242}$ Nor is there any indication that the federal courts are disrupting the development of California law. ${ }^{243}$ The California courts have not disagreed with the federal interpretation of the No Preference Clause and have in fact relied on the Ninth Circuit's interpretation of some provisions of the California Constitution. ${ }^{244}$

\section{Federal Courts and State Law}

Viewing federal adjudication of a state constitutional claim as a positive good, rather than as a necessary evil, helps define the proper approach to addressing dual constitutional challenges. This insight, however, is by no means dispositive. The foregoing discussion merely explains why such interests as cross-pollination and the insulation of constitutional decision makers might weigh in favor of a federal court's addressing state constitutional issues. In each case, a federal court must choose among: (1) adjudicating the federal claim; (2) adjudicating the state claim; or (3) abstaining to allow a state court to adjudicate the state claim. The

240. Van Deerlin, supra note 235, at B-9. Appointed by President Nixon, Judge Thompson was described by one writer as a "conservative Republican." Lionel Van Deerlin, Cross Fire Legal Challenge is Demagoguery, SAN Diego Union-Tribune, Apr. 1, 1994, at B-5.

241. See 31 COUNCIL of STATE GovernMENTS, supra note 123, at 133 .

242. See also Carpenter v. City \& County of San Francisco, 93 F.3d 627 (9th Cir. 1996) (finding cross in San Francisco park violated No Preference Clause of California Constitution). As is often the case in controversial settings, the public officials have continued to try to avoid the judicial mandate. The City of San Diego attempted to retain the Mt. Soledad cross by selling a small plot of land under the cross to a private party. Again relying on the California Constitution, Judge Thompson found that the sale failed to cure the constitutional violation. See Murphy v. Bilbray, No. 90-134 GT, 89-820 GT, 1997 WL 754604, at *9-*11 (S.D. Cal. Sept. 18, 1997).

243. But cf. Lori A. Adasiewicz, Quetzalcoatl, Crosses and the New Constitutional Value of Multiculturalism, 25 Hastings CoNST. L.Q. 159 (1997) (criticizing Ninth Circuit's analysis of state and federal law in religious symbol cases).

244. See Savage v. Trammell Crow Co., 273 Cal. Rptr. 302, 310-11 (Cal. Ct. App. 1990) (citing Carreras v. City of Anaheim, 768 F.2d 1039 (9th Cir. 1985), as guide in interpreting the liberty of . speech clause of the California Constitution). 
complex interplay of jurisdictional factors requires a careful balancing of interests. ${ }^{245}$

\section{A. Interests Implicated by Dual Constitutional Challenges}

Principles of federalism suggest that federal courts should exercise caution in interfering in state administrative or regulatory processes. Federal adjudication of state constitutional claims, however, does not necessarily give rise to such concerns. A judicial decision has two aspects: an opinion, which interprets a rnle of law, and a judgment, which binds the parties. ${ }^{246}$ The federal court cannot establish an authoritative interpretation of state law. The federal court's construction of the law can be reversed by a state court in a future case, and of course the state law can be changed by the usual legislative or state constitutional processes. Federal constitutional rulings, by contrast, may establish fixed and unyielding rules of conduct. Avoiding federal constitutional decisions thus advances federalism by providing greater flexibility for state governmental action. Moreover, rooted in a different institutional context, federal courts may provide a useful alternative perspective on the interpretation of state law. Because the political insulation of the federal courts aligns with important principles of constitutionalism, the federal perspective on state constitutional provisions may prove particularly valuable.

The actual judgment in the case presents a greater threat of intrusion. Unlike the interpretive aspect of the opinion, the judgment does bind the parties to the dispute. Depending on the nature of the entity and the character of the action, the judgment may indeed have an intrusive aspect. The rule of Pennhurst ${ }^{247}$ constitutionalizes this concern, prohibiting such an intrusion when the defendant is the state itself. As a federal court cannot issue an opinion without a judgment, ${ }^{248}$ the intrusiveness of the judgment might weigh against a federal court's interpreting the state constitution in a particular case.

The availability of a federal forum for the vindication of federal rights also represents an important jurisdictional principle. Especially since

245. Some have criticized judicial balancing, especially in constitutional cases. See T. Alexander Aleinikoff, Constitutional Law in the Age of Balancing, 96 YALE L.J. 943 (1987). The interplay of conflicting principles implicated in dual constitutional challenges, though, invites a balancing approach. See Susan Bandes, The Idea of a Case, 42 Stan. L. Rev. 227, $295-96$ (1990) (defending the need for balancing of constitutional values in a jurisdictional context); $c f$. Ann Althouse, When to Believe a Legal Fiction: Federal Interests and the Eleventh Amendment, 40 Hastings L.J. 1123,1135 $\mathrm{n} .48$ (1989) (discussing use of balancing in a jurisdictional context).

246. See Edward A. Hartnett, A Matter of Judgment, Not a Matter of Opinion, 74 N.Y.U. L. REv. 123 (1999) (emphasizing distinction between the opinion and the judgment).

247. Pennhurst State Sch. \& Hosp. v. Halderman, 465 U.S. 89 (1984).

248. See FALLON, supra note 38, at $92-98$ (discussing prohibition on advisory opinions in federal courts). 
Brown v. Board of Education, ${ }^{249}$ federal courts have played a predominant role in preserving individual rights. Neither the theory nor the reality of the new judicial federalisin undercuts that federal role. Because of the important federal role in protecting civil liberties, doctrines have arisen to facilitate access to federal court. The importance of a federal forum finds recognition in such principles as the availability of supplemental jurisdiction, ${ }^{250}$ the rejection of a requirement to exhaust state remedies, ${ }^{251}$ and the reluctance to abstain in certain civil rights cases. ${ }^{252}$ These doctrines, which conform to a "neo-federalist"253 perspective on the role of federal courts, need not conflict with federalism, if federalisin is properly understood as a means of protecting individual liberty, not state dignity. Neo-federalism and paleo-federalism, ${ }^{254}$ though, do emphasize different aspects of federal-state relations, and harmonizing the principles in particular cases may prove difficult.

\section{B. Types of State Constitutional Provisions}

For the purposes of this discussion, state constitutional provisions can be divided into four categories: (1) provisions that have been interpreted to have the same meaning as analogous federal provisions; (2) specialized provisions that form part of an integrated regulatory regime; (3) provisions that parallel the Federal Constitution, but have been interpreted differently; and (4) general provisions that protect broad rights, but have no federal analogue. The first two categories present few problems. The last two raise much more difficult issues.

If the state constitution has the same meaning as the federal, then the federal court should decide the federal question, following the lead of the United States Supreme Court in Constantineau, ${ }^{255}$ Flores de Otero, ${ }^{256}$ and Midkiff. ${ }^{257}$ Avoidance of the federal constitutional issue is inpossible. Purporting to rest only on state grounds would be disingenuous and potentially confusing. Abstention would delay federal adjudication by unnecessarily

\footnotetext{
249. 347 U.S. 483 (1954).

250. See supra note 53 .

251. See supra note 78 and accompanying text.

252. See, e.g., supra note 66.

253. See Amar, supra note 211, at 1492-93; Amar, Neo-Federalist View, supra note 223, at 208 n.9.
}

254. I invoke this neologism to emphasize that "neo-federalism" is not somehow "less federalist" than a principle that advances state sovereignty or dignity as independent goals. The point of "neofederalism" is to recover a more authentic and theoretically defensible notion of federal-state relations. See Amar, supra 211, at 1426-27, 1492-93.

255. Wisconsin v. Constantineau, 400 U.S. 433 (1971).

256. Examining Bd. of Eng'rs, Architects and Surveyors v. Flores de Otero, 426 U.S. 572, 598

(1979).

257. Hawaii Hous. Auth. v. Midkiff, 467 U.S. 229, 237 n.4 (1984). 
diverting the federal claim through state court and would be pointless because the state court could not avoid the federal question.

By contrast, where the challenged state law forms part of an integrated regulatory scheme, clarification of the underlying state legal regime may serve important goals. In this situation, the constitutional character of the regulations is not especially significant. Before it holds that a state law violates the Federal Constitution, a federal court should be sure that it knows what the state law means. A federal court may itself construe the state provisions or, if the state law is genuinely uncertain, a federal court could invoke certification procedures. In the case of specialized state provisions, federal interpretation of state law would have less to contribute to a federal-state dialogue. When construing specialized provisions, federal courts would not be building on their federal constitutional experience. Prior federal decisions are likely to be of little guidance in helping a federal court to interpret a clause prohibiting a "special privilege of fishery."258 Even in this situation, though, a federal court should be reluctant to subject the federal claim to the delay inherent in abstention.

State constitutional provisions that parallel the Federal Constitution, but have been interpreted differently, present more complex problems. Some principles, though, appear with clarity. Abstention remains a poor option. Abstention imposes substantial burdens on the plaintiff, and a general policy of abstaining for dual constitutional challenges would route many federal constitutional claims through state court. Certification avoids some, but not all, of the problems associated with abstention, and dual constitutional challenges may not be suitable for certification. ${ }^{259}$ In the Califorma cross cases, for example, the key issue was the application of state law in a fairly complex factual setting. Federal adjudication will be superior to certification in this context, which involves applying settled state law to a controversial problem implicating minority rights. ${ }^{260}$ Abstention and certification avoid federal constitutional questions, but, following Siler, ${ }^{261}$ a federal court can achieve the same result by addressing the state claim.

Rejecting Pullman ${ }^{262}$ abstention still leaves the choice to the federal court of whether to begin with the state question or with the federal question. The policy of avoiding federal constitutional adjudication, along with

258. AlasKa Const. art. VIII, § 15; see Reetz v. Bozanich, 397 U.S. 82, 84 (1970).

259. See supra note 46 and accompanying text.

260. In certain kinds of cases, the advantages of federal adjudication might be less pronounced. For example, when the issue does not concern protecting individuals from majoritarian overrcaching, the different institutional context of the federal courts might have less significance. Due process issues sometimes involve merely requiring the government to deal fairly with all its citizens. See Kahn, supra note 182. Political independence would seem less important in such instances.

261. Siler v. Louisville \& Nashville R.R. Co., 213 U.S. 175 (1909).

262. Railroad Comm'n of Texas v. Pullman, 312 U.S. 496 (1941). 
the benefits of adding a federal voice to questions of state constitutional law, support the Siler approach of deciding the state-law issue first. On the other hand, federalism concerns underlying cases such as Pennhurst might counsel caution by a federal court in enforcing state law against local officials or entities. On balance, I believe that the potential benefits of allowing a dialogue, rather than a monologue, on state constitutional issues outweigh the potential harms outlined in the Court's opinion and in Professor Althouse's thoughtful gloss on Pennhurst. ${ }^{263}$ The authoritative voice clearly remains with the highest court in each judicial system. While acknowledging this authority, a federal court's decision on the state constitutional claim promotes dialogue in two respects: The federal voice is added to the state constitutional debate and, by avoiding the federal constitutional question, the federal court allows further debate on the federal constitutional issue.

As discussed above, federal adjudication need not constitute intrusion into state policies. Courts, though, should consider whether the judgment in a particular case presents special dangers of intrusiveness. Just as a court has discretion to decide whether to assert supplemental jurisdiction over a claim, ${ }^{264}$ so too does a court have discretion in deciding whether to rest its decision on state constitutional grounds. For example, a federal court might well be reluctant to adjudicate a state claim that would require ongoing supervision of state governmental agencies. Federal courts may contribute to the dialogue about the meaning of state constitutional law, but complex, intrusive remedies would likely best be left to state courts. ${ }^{265}$ Federal courts have a constitutional and statutory obligation to vindicate federal rights, including enforcement of required remedies. ${ }^{266}$ In the realm of state constitutional law, though, federalism suggests a more advisory, rather than supervisory, role.

This caution about controlling state agencies should serve to vindicate the interests underlying the Pennhurst decision. The central concern of

263. In an earlier work, I suggested that federal courts facing challenges to state actors based on both state law and the Federal Constitution should decide the federal claim first. See Schapiro, supra note 59, at 598-600. I offered that option primarily as an alternative to the Supreme Court's Pennhurst decision, which imposed a constitutional barrier to a federal court's enforcing state law against a state. The potential advantages of federal adjudication of state constitutional claims now convince me that with regard to state constitutional claims again st local officials or entities-defendants not protected by Pennhurst-a federal court generally should begin with the state constitutional claim.

264. See 28 U.S.C. $\$ 1367$ (c) (1994).

265. A similar concern for avoiding interference with state administrative processes underlies the doctrine of Burford abstention. See Burford v. Sun Oil Co., 319 U.S. 315 (1943); WRIGHT, supra note 40 , at $328-31$.

266. See Susan Bandes, Reinventing Bivens: The Self-Executing Constitution, 68 S. CAL. L. Rev. 289, 293-94 (1995); see also Marbury v. Madison, 5 U.S. (1 Cranch) 137, 163 (1803) ("The government of the United States has been emphatically termed a government of laws, and not of men. It will certainly cease to deserve this high appellation, if the laws furnish no remedy for the violation of a vested legal right."). 
Pennhurst was not federal interpretation of state law, but federally mandated restructuring of a state agency based on state law. ${ }^{267}$ To prevent such intrusion, the Supreme Court adopted an inflexible jurisdictional bar when the defendant is the state itself. ${ }^{268}$ The Court left open the way for a more flexible balancing of interests in other situations. In deciding how to address dual constitutional challenges, a court can take account of the problem of federal intrusion. The goal of federal adjudication of state constitutions is not to assert federal authority, but to offer interpretive guidance.

Broad state constitutional provisions without federal analogues present similar issues. Here, too, federal courts may offer a valuable perspective. Even if the Federal Constitution does not have an equal rights amendment ${ }^{269}$ or a specific guarantee of privacy, ${ }^{270}$ federal experience will likely prove relevant. In construing these general protections of individual rights, the federal court's different, more insulated, perspective may well prove useful. The disadvantages of abstention certainly remain in this setting. Abstention delays federal adjudication of the federal claim. Further, even if the state provision has no exact federal analogue, its application may prove sufficiently widespread to present the danger of turning abstention into a rule. For example, routing all gender discrimination cases through state court for an interpretation of a state equal rights amendment would impose an unwanted detour on a substantial number of federal constitutional claims.

\section{CONCLUSION}

In a world increasingly characterized by interstate and international transactions, disjunctions between the political body constituting the courts and the political body providing the law inevitably arise. ${ }^{271}$ Indeed, in the transnational realm, tribunals may enforce "world law"272 that owes its

267. See Dwyer, supra note 53, at 147-51. Focusing on the intrusive remedies at issue in Pennhurst, Professor Dwyer has argued that the case should be read to bar federal adjudication of supplemental state-law claims only in the institutional reform context. Id.

268. Commentators have criticized the Court's adoption of an inflexible, constitutional bar to address the potential problems arising from federal adjudication of state law. See Sehapiro, supra note 59 , at 598 \& n.121 (citing sources).

269. For a discussion of state constitutional protections of equal rights, see FrIESEN, supra note 6, at 145-97; Paul Benjamin Linton, State Equal Rights Amendments: Making a Difference or Making a Statement?, 70 TEMPLE L. REv. 907 (1997).

270. For a discussion of state constitutional privacy provisions, see FRIESEN, supra note 6, at 6869; Ken Gormley and Rhonda G. Hartman, Privacy and the States, 65 Temple L. Rev. 1279 (1992).

271. See Henkin, supra note 2, at 261 ("In civil adjudication ... the state of the forum is often applying its own rules of conflicts of law (private international law) to conclude that the substantive law of another state should govern.").

272. See Harold J. Berman, World Law, 18 FordHAM INT'L L.J. 1617 (1995) (discussing use of "world law," rather than "international law," to refer to transnational relations betwcen people, rather than nations). 
authority to no single sovereign. ${ }^{273}$ Problems of competence and uniformity accompany such intersystemic adjudication. Courts may have little familiarity with the law of another sovereign. They may misunderstand or misapply the relevant interpretive tools. Interpretations may vary across the courts of different systens, and different results may flow from different forums. As all practicing litigants know, choice of forum may matter as much as choice of law. ${ }^{274}$

To the extent one values a single, authoritative voice, this intersystemic adjudication is messy and even misguided. ${ }^{275}$ An interplay of interpretive voices can be confusing and disruptive. Polyphony can lead to cacophony. Yet if one views adjudication more as an evolving dialogue about appropriate norms than as an attenipt to end disputation, the reality of intersystemic adjudication may be liberating. Different voices may contribute to the search for norms, whether that search takes the form of an inquiry into the common-law understanding of liability or into the meaning of particular statutory or constitutional provisions. Especially when the matter involves general principles applicable to a broad range of human conduct in diverse geographical settings, territorial or systemic boundaries need not disqualify a court from making a valuable contribution to the ongoing interpretive exercise. ${ }^{276}$

Courts in the United States have much experience in addressing the problem of intersystemic adjudication. The existence of many contiguous states has produced a large font of "horizontal" choice-of-law issues. The existence of parallel state and federal court systems has produced a variety of "vertical" choice-of-law problems. Erie Railroad v. Tompkins ${ }^{277}$ provided one answer to these questions, requiring federal courts to defer to state courts' interpretations of their states' law. State courts, of course, must follow federal law as interpreted by the United States Supreme Court. Nevertheless, choice of forum continues to matter.

The different institutional characteristics of courts may give them divergent perspectives on common problems. All perspectives may be valuable, but all perspectives may not be of equal value. In some areas,

273. See Harold J. Berman \& Felix J. Dasser, The "New" Law Merchant and the "Old": Sources, Content, and Legitimacy, in Lex MERCATORIA AND ARBITRATION 53-69 (Thomas E. Carbonneau ed., 1998) (discussing existence of autonomous law merchant); see also HENKIN, supra note 2, at 33-38 (discussing place of customary law in international realm); Harold J. Berman, Toward an Integrative Jurisprudence: Politics, Morality, History, 76 CALIF. L. REv. 779, 797 (1988) (discussing former positivist view that international law could not exist without international sovereign).

274. See William W. PARK, INTERnational Forum SElection 183 (1995) ("[C] hoice of forum may determine the outcome of a dispute as much as the applicable substantive law.").

275. See Bassler \& Potenza, supra note 44, at 517 (raising specter of "confused and fragmented legal norms").

276. See Laurence R. Helfer \& Anne-Marie Slaughter, Toward a Theory of Effective Supranational Adjudication, 107 YALE L.J. 273, 323-26 (1997) (discussing dialogue and erossfertilization in supranational context).

277. 304 U.S. 64 (1938). 
state courts might have a great deal to teach federal courts. In other realms, federal courts appear to enjoy an institutional advantage. In the protection of individual rights against potential majoritarian threats, the political insulation of federal courts has generally served them well. Federal court interpretation of state constitutions presents the potential to continue those contributions. Federal courts will never play the dominant role in construing state charters, but their contributions may be important nevertheless. Particularly in light of the complex interplay of factors that govern allocation of cases between state and federal courts, the potential for a valuable federal contribution to state constitutional law demands recognition. Following the framework outlined here, federal and state courts may participate together in the development of constitutional law. These principles best ensure the vindication of state and federal constitutional rights, without undue intrusions into legitimate state or federal policies. 